Published in final edited form as:

J Org Chem. 2016 November 04; 81(21): 10383-10391. doi:10.1021/acs.joc.6b01366.

\title{
Design, Synthesis, and Biological Evaluation of Structurally Rigid Analogues of 4-(3-Hydroxyphenyl)piperidine Opioid Receptor Antagonists
}

\author{
Scott P. Runyon ${ }^{\dagger}$, Chad M. Kormos ${ }^{\dagger}$, Moses G. Gichinga ${ }^{\dagger}$, S. Wayne Mascarella ${ }^{\dagger}$, Hernán A. \\ Navarro ${ }^{\dagger}$, Jeffrey R. Deschamps ${ }^{\ddagger}$, Gregory H. Imler ${ }^{\perp}$, and F. Ivy Carroll ${ }^{*},, \|$ \\ ${ }^{\dagger}$ Research Triangle Institute, P.O. Box 12194, Research Triangle Park, North Carolina \\ 27709-2194, United States \\ ¥Naval Research Laboratory, Code 6910, 455 Overlook Avenue, Washington, D.C. 20375, United \\ States
}

\begin{abstract}
In order to gain additional information concerning the active conformation of the $\mathrm{N}$-substituted trans-3,4-dimethyl-4-(3-hydroxyphenyl)piperidine (1) class of opioid receptor antagonists, procedures were developed for the synthesis of structurally rigid $\mathrm{N}$-substituted-6-(3-hydroxyphenyl)3-azabicyclo[3.1.0] hexane and 3-methyl-4-(3-hydroxyphenyl)-4azabicyclo[4.1.0]heptanes. Evaluation of the conformationally constrained series in a $\left[{ }^{35} \mathrm{~S}\right] \mathrm{GTP} \gamma \mathrm{S}$ assay showed that structural rigid compounds having the 3-hydroxyphenyl group locked in the piperidine equatorial orientation had potencies equal to or better than similar compounds having more flexible structures similar to 1 . The studies of the rigid compounds also suggested that the 3 methyl group present in compound $\mathbf{1}$ type antagonists may not be necessary for their pure opioid antagonist properties.
\end{abstract}

\section{Graphical abstract}
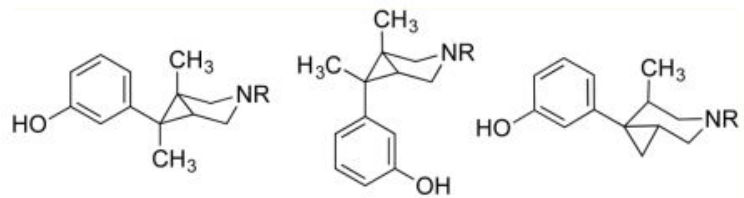

*Corresponding Author: fic@ rti.org.

IISHC member.

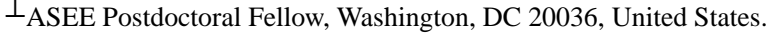

Notes

The authors declare no competing financial interest.

Supporting Information

The Supporting Information is available free of charge on the ACS Publications website at DOI: 10.1021/acs.joc.6b01366.

NMR spectra for isolated compounds (PDF)

$\mathrm{X}$-ray data for compound $\mathbf{6}$ (CIF)

$\mathrm{X}$-ray data for compound 27a (CIF) 


\section{INTRODUCTION}

$N$-Substituted trans-3,4-dimethyl-4-(3-hydroxyphenyl)-piperidines (1) are a class of pure opioid receptor antagonists with a novel pharmacophore. ${ }^{1}$ This pharmacophore has been used to design and develop several interesting opioid receptor antagonists. A few of the most studied compounds are LY255582 which was developed as a potential drug to treat obesity, LY246736 (alvimopan; ENTEREG, a drug on the market that accelerates the time to upper and lower GI recovery following surgeries that include partial bowel resection with primary anastomosis) and JDTic, a potent and selective $\boldsymbol{\kappa}$ opioid receptor antagonist as a potential pharmacotherapy for treating depression, anxiety, and substance abuse that reached phase 1 clinical studies. ${ }^{2}$ JDTic also proved highly useful for obtaining the X-ray structure of the human $\kappa$ opioid receptor. ${ }^{3}$

The SAR studies that led to the discovery of LY255582, LY246736, and JDTic all involved changes in the $N$-substituent of $\mathbf{1}$ (Figure 1). We have previously reported the synthesis of $\mathbf{2}$, $\mathbf{3}, \mathbf{4}$, and $\mathbf{5}$, also in this class. ${ }^{4}$ In this study we report the development of methods for the synthesis of $N$-substituted 6-(3-hydroxyphenyl)-3-azabicyclo[3.1.0]hexane analogues 6, 7, 8, 9, 10, and 11 and the $N$-substituted 3-methyl-4-(3-hydroxyphenyl)-4azabicyclo[4.1.0] heptanes $\mathbf{1 2}$ and 13, and compare their [ $\left.{ }^{35} \mathrm{~S}\right] \mathrm{GTP} \gamma \mathrm{S} K_{\mathrm{e}}$ values as opioid receptor antagonists to previously reported $N$-substituted trans-3,4-dimethyl-4-(3hydrophenyl)piperidines (1-5).

\section{RESULTS}

Compounds 6, 7, and 8 were synthesized as outlined in Scheme 1. ${ }^{5}$ Compounds $14 \mathbf{a}$ and 14b were condensed with hydrazine hydrate to provide the hydrazones $15 \mathbf{a}$ and $\mathbf{1 5 b}$, respectively. Oxidation of 15a and 15b with manganese dioxide in dioxane afforded the diazo compounds, which were reacted directly with the appropriate $\mathrm{N}$-methylmaleimide to afford the imides 16a-c. In the presence of boron trifluoride diethyl etherate, sodium borohydride reduced the imides to provide the amines 17a-c. Demethylation of aryl methyl ethers 17a-c was achieved using boron tribromide followed by the treatment of the resulting intermediate with refluxing piperazine to obtain target compounds $\mathbf{6 , 7}$, and $\mathbf{8}$.

The synthesis of $\mathbf{9}$ and $\mathbf{1 0}$ is outlined in Scheme 2. The diazo intermediate from $\mathbf{1 5 b}$ (Scheme 1) was reacted with $N$-benzylmaleimide 18 to afford the 3-aza-[3.1.0]-bicyclo compounds 19a and 19b. Diborane reduction of the imides in tetrahydrofuran yielded 20a and 20b. Demethylation of the aryl methyl ethers was effected with boron trichloride and tetrabutylammonium iodide ${ }^{6}$ in dichloromethane to afford the phenols $\mathbf{2 1 a}$ and $\mathbf{2 1 \mathbf { b }}$, which were converted to the phenyl acetates 22a and $\mathbf{2 2} \mathbf{b}$ for ease of handling. Catalytic hydrogenation afforded the secondary amines, which were alkylated with trans-2methylcinnamaldehyde and sodium cyanoborohydride. Finally, acetate hydrolysis afforded 9 and $\mathbf{1 0 .}$

The cyclopropanation reaction, which afforded $\mathbf{1 9 b}$, was found to produce a small yield of a competing product $\mathbf{2 3}$. The diastereomer $\mathbf{2 3}$ was separated by chromatography and carried

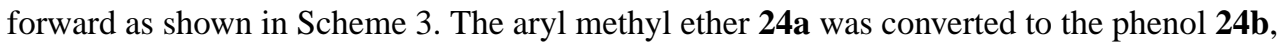


which was masked as the phenyl mesylate $\mathbf{2 4 c}$. Hydrogenation afforded the secondary amine 24d, which was reductively alkylated with 2-methyl-cinnamaldehyde to afford the penultimate intermediate 24e. Mesylate hydrolysis afforded the final product $\mathbf{1 1}$.

A review of the literature confirms cyclopropanation of alternately substituted maleimides proceeds with high selectivity for the 6-exo-product where the largest group from the diazo compound is oriented away from the formed [3.1.0] ring system. ${ }^{7-9}$ The groups at the 5- and 6-positions of 16a-c and 19a-b are stereospecifically fixed upon the same face via the 1,3dipolar cycloaddition forming the pyrazoline prior to denitrogenation. X-ray analysis of 6 (see Figure $\mathrm{S} 1$ in Supporting Information) confirms the exo configuration was exclusively obtained in 16a. Depending on the size of groups involved, a small amount of the competing endo-product (such as 23) may also be formed. In the case of $\mathbf{1 9 b}$ and 23, ROESY analysis of the major product $19 \mathrm{~b}$ revealed a through space correlation between the $\delta 1.236$-endo methyl (assigned by HMBC correlation with the $\delta 142.4$ aromatic carbon) and the $\delta 4.61 \mathrm{~N}$ benzyl methylene. Importantly, no correlation between the $N$-benzyl methylene and the electron-rich aromatic protons of the 6-exo-(3-methoxyphenyl) was observed. These observations support the assignment of $\mathbf{1 9 b}$ as the exo-product and $\mathbf{2 3}$ as the minor, endoproduct.

The major products $\mathbf{7}, \mathbf{8}, \mathbf{9}$, and 10 were therefore assigned analogous $(1 a, 5 a, 6 a)$ stereochemistry. The relative stereochemistry of the minor product $\mathbf{1 1}$ (arising from $\mathbf{2 3}$ ) has been assigned $(1 a, 5 a, 6 \beta)$. As can be seen in Figure 2, this results in the 6-(3-

hydroxyphenyl) occupying the opposite ( $\beta$ ) face of the cyclopropane relative to the 1-methyl and 3-hydro substituents on the primary ( $a$ ) face of the ring. The $(1 a, 5 a, 6 a)$ geometry of $\mathbf{6}$, $\mathbf{7}, \mathbf{8}, \mathbf{9}, 10$ compares favorably to the natural conformation of $\mathrm{N}$-substituted trans-3,4dimethyl-4-(3-hydroxyphenyl)-piperidines (1) such as 4, 5, LY255582, and JDTic (Figure $1)$.

Compounds 12 and 13 were prepared from the corresponding pure enantiomers as shown in Scheme 4. Demethylation of $N$-methyl-1,2,3,6-tetrahydropyridine 25a afforded the secondary amine $\mathbf{2 5 b}{ }^{10}$ The amine was converted to the trifluoro-methylsulfonamide $\mathbf{2 5 c}$. Cyclopropanation with dibromocarbene proceeded stereoselectively on the face opposite the 3-methyl of $\mathbf{2 5 c}$ to afford the intermediate $\mathbf{2 6} .{ }^{11}$ Reduction of the dibromide proceeded concomitant to the triflamide hydrolysis yielding the piperidine $\mathbf{2 7 a},{ }^{12}$ which was subjected to X-ray analysis to confirm the structure and relative stereochemistry (see Figure S2 in Supporting Information). Deprotection to the phenol $\mathbf{2 7 b}$ and reductive amination with 2cinnamylaldehyde afforded to final product $\mathbf{1 2}$.

In this study, we compared the opioid receptor properties of structurally rigid $\mathbf{6 , 7 , 8 , 1 0 , 1 1}$, $\mathbf{1 3}$, and $\mathbf{1 2}$ to the corresponding $\mathrm{N}$-substituted trans-3,4-dimethyl-4-(3-

hydroxyphenyl)piperidine analogs $\mathbf{2}, \mathbf{3}, \mathbf{4}$, and $\mathbf{5}$ (Table 1). ${ }^{4}$ Compound $\mathbf{8}$ has $K_{\mathrm{e}}=18,244$, and $42 \mathrm{nM}$ at the $\mu, \delta$, and $\kappa$ opioid receptors compared to $K_{\mathrm{e}}=29.3,681$, and $134 \mathrm{nM}$ at the $\mu, \delta$, and $\kappa$ receptors for $\mathbf{4}$. Thus, the in vitro antagonist activity for $\mathbf{8}$ is a little bit better than that for $\mathbf{4}$ at all three opioid receptors. Compound 7 has $K_{\mathrm{e}}=241$ and $479 \mathrm{nM}$ at the $\mu$ and $\kappa$ opioid receptors, compared to $K_{\mathrm{e}}=974$ and $479 \mathrm{nM}$ at the $\mu$ and $\delta$ receptors for 3 . Thus, 7 is also slightly better than $\mathbf{3}$ at the $\mu$ and $\kappa$ opioid receptors. Compound $\mathbf{3}$ was an agonist at the 
$\delta$ receptor, whereas 7 is an antagonist with $K_{\mathrm{e}}=2390 \mathrm{nM}$. Both $\mathbf{6}$ and 2 lack antagonist activity at the $\mu$ and $\delta$ opioid receptors and have very little antagonist activity at the $\kappa$ opioid receptor. The $N$-2-methylcinnamyl analog 10 has $K_{\mathrm{e}}=0.02,0.74$, and $0.39 \mathrm{nM}$ at the $\mu, \delta$, and $x$ opioid receptors, respectively, compared to $K_{\mathrm{e}}=0.08,1.21$, and $0.44 \mathrm{nM}$ at the $\mu, \delta$, and $\boldsymbol{\kappa}$ receptors, respectively, for $\mathbf{5}$ and, thus, has slightly better antagonist activity than $\mathbf{5}$ at the $\mu$ and $\delta$ opioid receptors $\left(K_{\mathrm{e}}=0.08\right.$ and $\left.1.21 \mathrm{nM}\right)$ and almost identical antagonism at the $\kappa$ opioid receptor $\left(K_{\mathrm{e}}=0.44 \mathrm{nM}\right)$. In contrast $11\left(K_{\mathrm{e}}=54.6,85\right.$ and IA at the $\mu, \delta$, and $\kappa$ receptors, respectively), which has the 3,4-dimethyl groups in a cis relationship, is much less potent than $\mathbf{1 0}$ and $\mathbf{5}$, which have the 3,4-dimethyl groups in a trans relationship. The $\mathrm{N}-2$ methylcinnamyl analog 9 which does not have a 3-methyl group remains a pure opioid receptor antagonist with $K_{\mathrm{e}}=0.48,8.8$, and $2.9 \mathrm{nM}$ at the $\mu, \delta$, and $\kappa$ opioid receptors, respectively, and thus has a little less antagonist potency than $\mathbf{5}$ at all three opioid receptors.

\section{DISCUSSION}

Synthetic procedures were developed for the synthesis of structurally rigid $\mathrm{N}$-substituted 6(3-hydrophenyl)-3-azabicyclo-[3.10]hexane and 3-methyl-4-(3-hydroxyphenyl)-4azabicyclo-[4.1.0]heptanes of the 3,4-dimethyl-4-(3-hydroxyphenyl)-piperidine class of opioid receptor antagonists and were used to synthesize analogs $6,7,8,10,11,13$, and 12 .

Results from early NMR studies of trimethyl-substituted 4-(3-hydroxyphenyl)-piperidines suggested that a 3-hydroxyphenyl equatorial piperidine chair conformation mediated the opioid antagonist properties of the trans-3,4-dimethyl-4-(3-hydroxyphenyl)-piperidine class of opioid antagonist. ${ }^{13,14}$ At this point in time it was also thought that the presence of the 3methyl group on the piperidine ring was necessary for the opioid receptor antagonists' properties. Evaluation of the compounds in this study for their opioid properties using an $\left[{ }^{35} \mathrm{~S}\right] \mathrm{GTP} \gamma \mathrm{S}$ assay showed that each of the analogs which have the 3-hydroxyphenyl group locked in an equatorial orientation were an opioid receptor antagonist with efficacy at least as good as the corresponding trans-1,3-dimethyl-4-(3-hydroxyphenyl)-piperidine compound, and in the case of $\mathbf{1 0}$, its antagonist activity was slightly better than that of the corresponding 5.

In order to determine the importance of the 1-methyl group (equivalent to the 3-methyl in the 3,4-dimethylpiperidine class of antagonist) of the 1,6-dimethyl-3azabicyclo[3.1.0] hexane ring system of 10, we synthesized and evaluated the 1-desmethyl analog $\mathbf{9}$. We found that $\mathbf{9}$, which also has the 3-hydroxyphenyl group in a locked equatoriallike orientation, was a pure opioid receptor antagonist with $K_{\mathrm{e}}$ 's of $0.48,8.6$, and $2.9 \mathrm{nM}$ at the $\mu, \delta$, and $\kappa$ opioid receptors suggesting that the 3-position methyl group on 1 may not be needed for its opioid antagonist receptor of 10. Although functional antagonism was not affected by the lack of a 1-position methyl group in the azabicyclo[3.1.0]hexanes series, the absence of a methyl group in this position did result in a small decrease in potency.

\section{EXPERIMENTAL SECTION}

Melting points were determined using a capillary melting point apparatus and are uncorrected. Nuclear magnetic resonance $\left({ }^{1} \mathrm{H}\right.$ NMR and ${ }^{13} \mathrm{C}$ NMR $)$ spectra were obtained 
on a $500 \mathrm{MHz}$ NMR spectrometer or a $300 \mathrm{MHz}$ NMR spectrometer. Chemical shifts are reported in parts per million (ppm) with reference to internal solvent. Mass spectra (MS) were conducted on a mass spectrometer equipped with an ESI (turbospray) source. Elemental analyses were performed by an external laboratory. The purity of the compounds $(>95 \%)$ was established by elemental analysis. Optical rotations were measured on an automatic polarimeter. Analytical thin-layer chromatography (TLC) was carried out using silica gel $60 \mathrm{~F}_{254}$ TLC plates. TLC visualization was achieved with a UV lamp or in an iodine chamber. Flash column chromatography was done on a system using prepacked silica gel columns or using silica gel 60A (230-400 mesh). Solvent system: CMA80 80:18:2 $\mathrm{CHCl}_{3} / \mathrm{MeOH} /$ conc. $\mathrm{NH}_{4} \mathrm{OH}$. Unless otherwise stated, reagent-grade chemicals were obtained from commercial sources and were used without further purification. All moistureand air-sensitive reactions and reagent transfers were carried out under dry nitrogen.

3-[(1 $a, 5 a, 6 a)$-3-Methyl-3-azabicyclo[3.1.0]hex-6-yl]phenol (6)—Boron tribromide (1 $\mathrm{M}$ solution in $\mathrm{CH}_{2} \mathrm{Cl}_{2}, 5.4 \mathrm{~mL}$ ) was added dropwise to a solution of $\mathbf{1 7 a}$ (500 mg, 2.5 $\mathrm{mmol})$ in dichloromethane $(25 \mathrm{~mL})$ at $-78{ }^{\circ} \mathrm{C}$ under $\mathrm{N}_{2}$. The reaction mixture was allowed to warm to room temperature overnight. The reaction mixture was cooled to $-78{ }^{\circ} \mathrm{C}$, treated with $\mathrm{MeOH}(20 \mathrm{~mL})$, warmed to $\mathrm{rt}$, and stirred for $10 \mathrm{~min}$. The methanol was evaporated. The residue was partitioned between EtOAc and aq. piperazine. The resulting biphasic mixture was heated to reflux. Upon cooling, the organic layer was separated and concentrated. The residue was subjected to chromatography on silica gel eluting with a gradient of CMA80 in $\mathrm{CH}_{2} \mathrm{Cl}_{2}$ to afford $6(59.6 \mathrm{mg}, 13 \%)$ as a white solid. Mp 131$132{ }^{\circ} \mathrm{C} ;{ }^{1} \mathrm{H}$ NMR $\left(500 \mathrm{MHz}, \mathrm{CDCl}_{3}\right) \delta 7.08(\mathrm{t}, J=7 \mathrm{~Hz}, 1 \mathrm{H}), 6.59(\mathrm{~m}, 2 \mathrm{H}), 6.49(\mathrm{~m}, 1 \mathrm{H})$, $3.13(\mathrm{~d}, J=10 \mathrm{~Hz}, 2 \mathrm{H}), 2.48(\mathrm{~d}, J=10 \mathrm{~Hz}, 2 \mathrm{H}), 2.37(\mathrm{~s}, 3 \mathrm{H}), 2.20(\mathrm{~m}, 1 \mathrm{H}), 1.70(\mathrm{~s}$, $2 \mathrm{H}) ;{ }^{13} \mathrm{C} \mathrm{NMR}\left(125 \mathrm{MHz}, \mathrm{CDCl}_{3}\right) \delta 156.1,144.4,129.4,112.9,64.9,57.7,41.5,27.9,24.9$; LRMS (ESI-quadrupole) $\mathrm{m} / z 190.3\left(\mathrm{M}+\mathrm{H}^{+}\right)$. Anal. Calcd for $\mathrm{C}_{12} \mathrm{H}_{15} \mathrm{NO}: \mathrm{C}, 76.16 ; \mathrm{H}$, 7.99; N, 7.40. Found: C, 75.74; H, 7.71; N, 7.39.

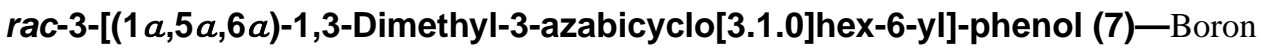
tribromide (1 M solution in $\mathrm{CH}_{2} \mathrm{Cl}_{2}, 4.8 \mathrm{~mL}$ ) was added dropwise to a solution of $\mathbf{1 7 b}$ (500 $\mathrm{mg}, 2.3 \mathrm{mmol})$ in dichloromethane $(25 \mathrm{~mL})$ at $-78{ }^{\circ} \mathrm{C}$ under $\mathrm{N}_{2}$. The reaction mixture was allowed to warm to room temperature overnight. The reaction mixture was cooled to $-78{ }^{\circ} \mathrm{C}$, treated with $\mathrm{MeOH}(20 \mathrm{~mL})$, warmed to room temperature, and stirred for $10 \mathrm{~min}$. The methanol was evaporated. The residue was partitioned between EtOAc and aq. piperazine. The resulting biphasic mixture was heated to reflux. Upon cooling, the organic layer was separated and concentrated. The residue was subjected to chromatography on silica gel eluting with a gradient of CMA80 in $\mathrm{CH}_{2} \mathrm{Cl}_{2}$ to afford $7(95.1 \mathrm{mg}, 19 \%)$ as a white crystalline solid. Mp 150-152 ${ }^{\circ} \mathrm{C} ;{ }^{1} \mathrm{H}$ NMR $\left(300 \mathrm{MHz}, \mathrm{CDCl}_{3}\right) \delta 7.17(\mathrm{t}, J=8 \mathrm{~Hz}, 1 \mathrm{H})$, $6.95(\mathrm{~d}, J=8 \mathrm{~Hz}, 1 \mathrm{H}), 6.70(\mathrm{~d}, J=7 \mathrm{~Hz}, 1 \mathrm{H}), 6.46(\mathrm{~s}, 1 \mathrm{H}), 3.42(\mathrm{~m} \mathrm{2H}), 2.63(\mathrm{~d}, J=10 \mathrm{~Hz}$, 2H), 2.38 (s, 3H), 2.08 (s, 2H), 1.39 (s, 3H); LRMS (ESI-quadrupole) $\mathrm{m} / z 204.6\left(\mathrm{M}+\mathrm{H}^{+}\right.$). Anal. Calcd for $\mathrm{C}_{13} \mathrm{H}_{17} \mathrm{NO}$ : C, 76.81; H, 8.43; N, 6.89. Found: C, 76.69; H, 8.27; N, 6.95 .

rac-3-[(1 $a, 5 a, 6 a)-1,3,6$-Trimethyl-3-azabicyclo[3.1.0]hex-6-yl]phenol (8)—Boron tribromide ( $1 \mathrm{M}$ solution in $\mathrm{CH}_{2} \mathrm{Cl}_{2}, 1.82 \mathrm{~mL}$ ) was added dropwise to a solution of $17 \mathbf{c}$ (200 $\mathrm{mg}, 0.86 \mathrm{mmol})$ in dichloromethane $(20 \mathrm{~mL})$ at $-78{ }^{\circ} \mathrm{C}$ under $\mathrm{N}_{2}$. The reaction mixture was 
allowed to warm to room temperature overnight. The reaction mixture was cooled to $-78^{\circ} \mathrm{C}$, treated with $\mathrm{MeOH}(20 \mathrm{~mL})$, warmed to rt, and stirred for $10 \mathrm{~min}$. The methanol was evaporated. The residue was partitioned between EtOAc and aq. piperazine. The resulting biphasic mixture was heated to reflux. Upon cooling, the organic layer was separated and concentrated. The residue was subjected to chromatography on silica gel eluting with a gradient of CMA80 in $\mathrm{CH}_{2} \mathrm{Cl}_{2}$ to afford $\mathbf{8}$ as a white solid $(68.2 \mathrm{mg}, 36 \%)$. Mp 119$121{ }^{\circ} \mathrm{C} .{ }^{1} \mathrm{H}$ NMR $\left(300 \mathrm{MHz}, \mathrm{CDCl}_{3}\right) \delta 7.13(\mathrm{t}, J=8 \mathrm{~Hz}, 1 \mathrm{H}), 6.72(\mathrm{~d}, J=7 \mathrm{~Hz}, 1 \mathrm{H}), 6.65$ $(\mathrm{m}, 2 \mathrm{H}), 3.12(\mathrm{~m}, 1 \mathrm{H}), 2.87(\mathrm{~d}, J=10 \mathrm{~Hz}, 1 \mathrm{H}), 2.78(\mathrm{~d}, J=11 \mathrm{~Hz}, 2 \mathrm{H}), 2.34(\mathrm{~s}, 3 \mathrm{H}), 1.67$ (m, 1H), 1.40 (s, 3H), 0.94 (s, 3H); LRMS (ESI-quadrupole) $\mathrm{m} / z 218.5\left(\mathrm{M}+\mathrm{H}^{+}\right.$). Anal. Calcd for $\mathrm{C}_{14} \mathrm{H}_{19} \mathrm{NO}$ : C, 77.38; H, 8.81; N, 6.45. Found: C, 77.12; H, 8.75; N, 6.42.

\section{3-\{(1 $a, 5 a, 6 a)-6-M e t h y l-3-[(2 E)-3-(2-m e t h y l p h e n y l) p r o p-2-e n-1-y l]-3-$ azabicyclo[3.1.0]hex-6-yl\}phenol Oxalate (9)—A solution of $22 \mathrm{a}(860 \mathrm{mg}, 2.68$} $\mathrm{mmol})$ in $\mathrm{EtOH}(35 \mathrm{~mL})$ was added to a Parr hydrogenation bottle under $\mathrm{N}_{2}$. Solid $10 \%$ $\mathrm{Pd} / \mathrm{C}(1.0 \mathrm{~g})$ was added followed by a $1.0 \mathrm{M}$ solution of $\mathrm{HCl}$ in $\mathrm{Et}_{2} \mathrm{O}(2.68 \mathrm{~mL}, 2.68 \mathrm{mmol})$, and the solution was hydrogenated at 40 psi for $8 \mathrm{~h}$. The solution was then filtered through a pad of Celite and concentrated under reduced pressure to afford 3-[(1a,5a,6a)-6-methyl-3azabicyclo[3.1.0]hex-6-yl]phenyl acetate as the $\mathrm{HCl}$ salt $(0.92 \mathrm{~g}, 88 \%)$. A solution of trans-2-methylcinnamaldehyde $(80.0 \mathrm{mg}, 0.51 \mathrm{mmol})$ in 1,2-dichloroethane $(10 \mathrm{~mL})$ was then added to a suspension of 3-[(1a,5a,6a)-6-methyl-3-azabicyclo[3.1.0]hex-6-yl]phenyl acetate $(100 \mathrm{mg}, 0.43 \mathrm{mmol})$ and sodium triacetoxyborohydride $(130 \mathrm{mg}, 0.65 \mathrm{mmol})$ in 1,2-dichloroethane $(30 \mathrm{~mL})$. The suspension was allowed to stir at room temperature for $4 \mathrm{~h}$ and was diluted with a saturated solution of $\mathrm{NaHCO}_{3}(10 \mathrm{~mL})$ and extracted with $\mathrm{CH}_{2} \mathrm{Cl}_{2}$ (3 $\times 50 \mathrm{~mL})$. The resulting extracts were combined, dried $\left(\mathrm{MgSO}_{4}\right)$, and concentrated under reduced pressure to afford an oil that was purified using silica gel chromatography $\left(\mathrm{CHCl}_{3}\right.$, $\left.\mathrm{MeOH}, \mathrm{NH}_{4} \mathrm{OH} ; 90: 9: 1\right)$ to provide 3-\{(1a,5a,6a)-6-methyl-3-[(2E)-3-(2methylphenyl)prop-2-en-1-yl]-3-azabicyclo[3.1.0]hex-6-yl $\}$ phenyl acetate $(0.065 \mathrm{~g}, 42 \%)$ as a colorless oil. Solid $\mathrm{K}_{2} \mathrm{CO}_{3}(120 \mathrm{mg}, 0.90 \mathrm{mmol})$ was added to a solution of 3-\{(1a,5a, 6a)-6-methyl-3-[(2E)-3-(2-methylphenyl)prop-2-en-1-yl]-3-azabicyclo[3.1.0]hex-6yl \} phenyl acetate in $\mathrm{MeOH}(5 \mathrm{~mL})$ and $\mathrm{H}_{2} \mathrm{O}(2 \mathrm{~mL})$. The solution was allowed to stir at room temperature for $2 \mathrm{~h}$ and was acidified with $1.0 \mathrm{M} \mathrm{HCl}$, made basic with $\mathrm{NaHCO}_{3}$, and extracted with EtOAc $(3 \times 25 \mathrm{~mL})$. The organic extracts were combined, dried $\left(\mathrm{MgSO}_{4}\right)$, and concentrated under reduced pressure. The resulting oil was purified on silica gel chromatography $\left(\mathrm{CHCl}_{3}, \mathrm{MeOH}, \mathrm{NH}_{4} \mathrm{OH} ; 80: 18: 2\right)$ to afford pure 3-\{(1a,5a,6a)-6methyl-3-[(2E)-3-(2-methylphenyl)prop-2-en-1-yl]-3-azabicyclo[3.1.0]hex-6-yl \}phenol $(0.05 \mathrm{~g}, 83 \%)$ as the free base: ${ }^{1} \mathrm{H}$ NMR $(300 \mathrm{MHz}, \mathrm{MeOD}) \delta 7.42(\mathrm{td}, J=2.3,4.5 \mathrm{~Hz}, 1 \mathrm{H})$, 7.24-6.96 (m, 4H), $6.82(\mathrm{~d}, J=15.4 \mathrm{~Hz}, 1 \mathrm{H}), 6.75-6.64(\mathrm{~m}, 2 \mathrm{H}), 6.56(\mathrm{dd}, J=2.4,8.1 \mathrm{~Hz}$, $1 \mathrm{H}), 6.12(\mathrm{td}, J=6.5,15.5 \mathrm{~Hz}, 1 \mathrm{H}), 3.38-3.25(\mathrm{~m}, 3 \mathrm{H}), 3.13-3.00(\mathrm{~m}, 2 \mathrm{H}), 2.87$ (d, $J=10.5$ $\mathrm{Hz}, 2 \mathrm{H}), 2.33$ (s, 3H), 1.86 (br. s., $2 \mathrm{H}), 1.44$ (s, 3H). The salt was formed by dissolving the free base and 1.1 equiv of oxalic acid in acetone $(10 \mathrm{~mL})$ followed by gentle heating and cooling to induce precipitation. The collected solids were then recrystallized from acetone and EtOAc to afford 9 as a white solid. Mp 161-162 ${ }^{\circ} \mathrm{C}$. Anal. Calcd for $\mathrm{C}_{22} \mathrm{H}_{25} \mathrm{NO} \cdot \mathrm{C}_{2} \mathrm{H}_{2} \mathrm{O}_{4}$ : C, 70.40; H, 6.65; N, 3.42. Found: C, 70.18; H, 6.61; N, 3.41. 
rac-3-\{(1 $a, 5 a, 6 a)-1,6-D i m e t h y l-3-[(2 E)-3-(2-m e t h y l p h e n y l)-p r o p-2-e n-1-y \mid]-3-$ azabicyclo[3.1.0]hex-6-yl\}phenol Resorcylate (10)—A solution of $22 \mathrm{~b}$ (1.12 g, $0.0033 \mathrm{~mol}$ in $\mathrm{EtOH}\left(30 \mathrm{~mL}\right.$ ) was added to a Parr hydrogenation bottle under $\mathrm{N}_{2}$. Solid $10 \%$ $\mathrm{Pd} / \mathrm{C}(0.20 \mathrm{~g})$ was added followed by a $1.0 \mathrm{M}$ solution of $\mathrm{HCl}$ in $\mathrm{Et}_{2} \mathrm{O}(3.34 \mathrm{~mL}, 3.34$ $\mathrm{mmol}$ ), and the solution was hydrogenated at $40 \mathrm{psi}$ for $8 \mathrm{~h}$. The solution was then filtered through a pad of Celite and concentrated under reduced pressure to afford rac-3-[(1a,5a, 6a)-1,6-dimethyl-3-azabicyclo[3.1.0]hex-6-yl]phenyl acetate as the $\mathrm{HCl}$ salt (0.92 g, 88\%). A solution of trans-2-methylcinnamaldehyde $(0.66 \mathrm{~g}, 4.5 \mathrm{mmol})$ in 1,2-dichloroethane (10 $\mathrm{mL}$ ) was then added to a suspension of rac-3-[(1a,5a,6a)-1,6-dimethyl-3azabicyclo[3.1.0]hex-6-yl]phenyl acetate $(920 \mathrm{mg}, 3.75 \mathrm{mmol})$ and sodium triacetoxyborohydride $(1.19 \mathrm{~g}, 0.0057 \mathrm{~mol})$ in 1,2-dichloroethane $(30 \mathrm{~mL})$. The suspension was allowed to stir at room temperature for $4 \mathrm{~h}$ and was diluted with a saturated solution of $\mathrm{NaHCO}_{3}(30 \mathrm{~mL})$ and extracted with $\mathrm{CH}_{2} \mathrm{Cl}_{2}(3 \times 50 \mathrm{~mL})$. The resulting extracts were combined, dried $\left(\mathrm{MgSO}_{4}\right)$, and concentrated under reduced pressure to afford an oil that was purified using silica gel chromatography $\left(\mathrm{CHCl}_{3}, \mathrm{MeOH}, \mathrm{NH}_{4} \mathrm{OH} ; 90: 9: 1\right)$ to provide rac-3$\{(1 a, 5 a, 6 a)-1,6$-dimethyl-3-[(2E)-3-(2-methylphenyl)prop-2-en-1-yl]-3azabicyclo[3.1.0]hex-6-yl $\}$ phenyl acetate $(0.30 \mathrm{~g}, 21 \%)$ as a colorless oil. Solid $\mathrm{K}_{2} \mathrm{CO}_{3}$ $(0.64 \mathrm{~g}, 4.63 \mathrm{mmol})$ was added to a solution of rac-3-\{(1a,5a,6a)-1,6-dimethyl-3-[(2E)-3(2-methylphenyl)prop-2-en-1-yl]-3-azabicyclo[3.1.0]hex-6-yl\}phenyl acetate in $\mathrm{MeOH}$ (9.5 $\mathrm{mL})$ and $\mathrm{H}_{2} \mathrm{O}(6.5 \mathrm{~mL})$. The solution was allowed to stir at room temperature for $2 \mathrm{~h}$ and was acidified with $1.0 \mathrm{M} \mathrm{HCl}$, made basic with $\mathrm{NaHCO}_{3}$ and extracted with EtOAc $(3 \times 25$ $\mathrm{mL})$. The organic extracts were combined, dried $\left(\mathrm{MgSO}_{4}\right)$, and concentrated under reduced pressure. The resulting oil was purified on silica gel chromatography $\left(\mathrm{CHCl}_{3}, \mathrm{MeOH}\right.$, $\left.\mathrm{NH}_{4} \mathrm{OH} ; 80: 18: 2\right)$ to afford pure rac-3-\{(1a,5a,6a)-1,6-dimethyl-3-[(2E)-3-(2methylphenyl)prop-2-en-1-yl]-3-azabicyclo[3.1.0]hex-6-yl $\}$ phenol $(0.14 \mathrm{~g}, 50 \%)$ as the free base: ${ }^{1} \mathrm{H}$ NMR $\left(300 \mathrm{MHz}, \mathrm{CDCl}_{3}\right) \delta$ 7.48-7.21 (m, 2H), 7.20-7.04 (m, 4H), 6.82-6.56 (m, $4 \mathrm{H}), 6.14(\mathrm{td}, J=6.6,15.4 \mathrm{~Hz}, 1 \mathrm{H}), 3.33(\mathrm{~d}, J=6.4 \mathrm{~Hz}, 2 \mathrm{H}), 3.21(\mathrm{dd}, J=5.7,10.2 \mathrm{~Hz}, 1 \mathrm{H})$, 2.99-2.85 (m, 2H), $2.82(\mathrm{~d}, J=10.2 \mathrm{~Hz}, 1 \mathrm{H}), 2.32(\mathrm{~s}, 3 \mathrm{H}), 1.67$ (d, $J=4.9 \mathrm{~Hz}, 1 \mathrm{H}), 1.46-$ $1.36(\mathrm{~m}, 3 \mathrm{H}), 0.92(\mathrm{~s}, 3 \mathrm{H})$. The salt was formed by dissolving 1.1 equiv of 3,5dihydroxybenzoic acid in $\mathrm{MeOH}(1 \mathrm{~mL})$ and adding it to the free base in $\mathrm{MeOH}(3 \mathrm{~mL})$ followed by $\mathrm{Et}_{2} \mathrm{O}(10 \mathrm{~mL})$ to induce precipitation. The collected solids were then recrystallized from $\mathrm{MeOH}$ and EtOAc to afford $\mathbf{1 0}$ as a white solid. Mp $136-138{ }^{\circ} \mathrm{C}$. Anal. Calcd for $\mathrm{C}_{23} \mathrm{H}_{27} \mathrm{NO} \cdot \mathrm{C}_{7} \mathrm{H}_{6} \mathrm{O}_{4} \cdot 1.25 \mathrm{H}_{2} \mathrm{O}: \mathrm{C}, 70.64 ; \mathrm{H}, 7.01 ; \mathrm{N}, 2.74$. Found: $\mathrm{C}, 70.38 ; \mathrm{H}$, $6.75 ; \mathrm{N}, 2.63$.

\section{rac-3-\{(1 $a, 5 a, 6 \beta)$-1,6-Dimethyl-3-[(2E)-3-(2-methylphenyl)-prop-2-en-1-yl]-3- azabicyclo[3.1.0]hex-6-yl\}phenol Resorcylate (11)—A 1.0 M solution of $\mathrm{NaOH}$ (10} $\mathrm{mL})$ was added to a solution of $24 \mathrm{e}(110 \mathrm{mg}, 0.27 \mathrm{mmol})$ in $\mathrm{MeOH}(25 \mathrm{~mL})$ at $0{ }^{\circ} \mathrm{C}$. The

solution was allowed to warm to room temperature over $4 \mathrm{~h}$ and was made acidic with $1.0 \mathrm{M}$ $\mathrm{HCl}$, made basic with $\mathrm{NaHCO}_{3}$, and extracted with EtOAc $(3 \times 25 \mathrm{~mL})$. The organic extracts were combined, dried $\left(\mathrm{MgSO}_{4}\right)$, and concentrated under reduced pressure. The resulting oil was purified on silica gel chromatography $\left(\mathrm{CHCl}_{3}, \mathrm{MeOH}, \mathrm{NH}_{4} \mathrm{OH} ; 80: 18: 2\right)$ to afford rac-3-\{(1a,5a,6 $\beta)$-1,6-dimethyl-3-[(2E)-3-(2-methylphenyl)prop-2-en-1-yl]-3azabicyclo[3.1.0] hex-6-yl $\}$ phenol $(0.054 \mathrm{~g}, 60 \%)$ as a colorless oil: ${ }^{1} \mathrm{H}$ NMR $(300 \mathrm{MHz}$, $\left.\mathrm{CDCl}_{3}\right) \delta 7.24(\mathrm{~d}, J=3.8 \mathrm{~Hz}, 1 \mathrm{H}), 7.20-7.02(\mathrm{~m}, 4 \mathrm{H}), 6.67(\mathrm{~d}, J=7.5 \mathrm{~Hz}, 1 \mathrm{H}), 6.62-6.51$

J Org Chem. Author manuscript; available in PMC 2017 September 06. 
(m, 2H), 6.37 (d, $J=15.8 \mathrm{~Hz}, 1 \mathrm{H}), 5.62$ (td, $J=6.4,15.8 \mathrm{~Hz}, 1 \mathrm{H}), 5.30$ (br. s, 1H), 2.92 (dd, $J=3.4,9.4 \mathrm{~Hz}, 2 \mathrm{H}), 2.84(\mathrm{~d}, J=6.0 \mathrm{~Hz}, 2 \mathrm{H}), 2.73(\mathrm{dd}, J=4.3,9.6 \mathrm{~Hz}, 1 \mathrm{H}), 2.51$ (d, $J=9.4$ $\mathrm{Hz}, 1 \mathrm{H}), 2.25$ (s, 3H), $1.39(\mathrm{~s}, 3 \mathrm{H}), 1.24(\mathrm{~s}, 3 \mathrm{H}), 1.18(\mathrm{~d}, J=4.5 \mathrm{~Hz}, 1 \mathrm{H})$. The salt was formed by adding a solution of 1.1 equiv of 3,5-dihydroxybenzoic acid in $\mathrm{MeOH}(1 \mathrm{~mL})$ to the free base in $\mathrm{MeOH}(3 \mathrm{~mL})$ followed by $\mathrm{Et}_{2} \mathrm{O}(10 \mathrm{~mL})$ to induce precipitation. The collected solids were then recrystallized from $\mathrm{MeOH}$ and EtOAc to afford $\mathbf{1 1}$ as a white solid. Mp 126-128 ${ }^{\circ} \mathrm{C}$. Anal. Calcd for $\mathrm{C}_{23} \mathrm{H}_{27} \mathrm{NO}^{\mathrm{C}} \mathrm{C}_{7} \mathrm{H}_{6} \mathrm{O}_{4} \cdot \mathrm{H}_{2} \mathrm{O}$ : C, 71.26; H, 6.97; N, 2.77 . Found: C, 71.17; H, 6.71; N, 2.74 .

\section{3-\{(1R,5R,6S)-5-Methyl-3-[(2E)-3-(2-methylphenyl)prop-2-en-1-yl]-3-} azabicyclo[4.1.0]hept-6-yl\}phenol Resorcylate (12)—A solution of trans-2-

methylcinnamaldehyde (150 mg, $0.98 \mathrm{mmol})$ in 1,2-dichloroethane $(5 \mathrm{~mL})$ was then added to a suspension of $\mathbf{2 7 \mathbf { b }}(200 \mathrm{mg}, 1.06 \mathrm{mmol})$ and sodium triacetoxyborohydride $(250 \mathrm{mg}$, $1.18 \mathrm{mmol})$ in 1,2-dichloroethane $(15 \mathrm{~mL})$. The suspension was allowed to stir at room temperature for $4 \mathrm{~h}$ and was diluted with a saturated solution of $\mathrm{NaHCO}_{3}(50 \mathrm{~mL})$ and extracted with $\mathrm{CH}_{2} \mathrm{Cl}_{2}(3 \times 50 \mathrm{~mL})$. The resulting extracts were combined, dried $\left(\mathrm{MgSO}_{4}\right)$, and concentrated under reduced pressure to afford an oil that was purified using silica gel chromatography using petroleum ether, $\mathrm{Et}_{2} \mathrm{O}, \mathrm{TEA}(10: 9: 1)$ as eluents to provide $3-\{(1 R, 5 R$, 6S)-5-methyl-3-[(2E)-3-(2-methylphenyl)prop-2-en-1-yl]-3-azabicyclo[4.1.0]hept-6yl \}phenol (0.16 g, 56\%) as an oil: ${ }^{1} \mathrm{H}$ NMR $\left(300 \mathrm{MHz}, \mathrm{CDCl}_{3}\right) \delta 7.30-7.27(\mathrm{~m}, 1 \mathrm{H}), 7.05-$ $7.01(\mathrm{~m}, 4 \mathrm{H}), 6.97(\mathrm{~d}, J=7.8 \mathrm{~Hz}, 1 \mathrm{H}), 6.70-6.61(\mathrm{~m}, 3 \mathrm{H}), 6.53(\mathrm{dd}, J=8.0,2.0 \mathrm{~Hz}, 1 \mathrm{H})$, $6.03(\mathrm{dt}, J=9.0, \mathrm{~Hz} \mathrm{~Hz}, 1 \mathrm{H}) 3.08(\mathrm{~d}, J=6.6 \mathrm{~Hz}, 2 \mathrm{H}), 2.97(\mathrm{~d}, J=11.1 \mathrm{~Hz}, 1 \mathrm{H}), 2.66(\mathrm{dd}, J$ $=11.3,5.0 \mathrm{~Hz}, 1 \mathrm{H}), 2.53(\mathrm{dd}, J=11.4,4.5 \mathrm{~Hz}, 1 \mathrm{H}), 2.21(\mathrm{~s}, 3 \mathrm{H}), 2.18-2.07(\mathrm{~m}, 1 \mathrm{H}), 1.77(\mathrm{t}$, $J=10.4 \mathrm{~Hz}, 1 \mathrm{H}), 1.32-1.24(\mathrm{~m}, 1 \mathrm{H}), 0.85-0.76(\mathrm{~m}, 2 \mathrm{H}), 0.58$ (d, $J=15.9,6.6 \mathrm{~Hz}, 3 \mathrm{H})$. The resorcylate salt was formed by adding a solution of 1.1 equiv of 3,5-dihydroxybenzoic acid in $\mathrm{MeOH}(1 \mathrm{~mL})$ to the free base in $\mathrm{MeOH}(3 \mathrm{~mL})$ followed by $\mathrm{Et}_{2} \mathrm{O}(10 \mathrm{~mL})$ to induce precipitation. The collected solids were then recrystallized from $\mathrm{MeOH}$ and EtOAc to afford 12 as a white solid. Mp $155-157{ }^{\circ} \mathrm{C} ;[a]_{\mathrm{D}}^{22}-14.6$ (c 0.11, MeOH). Anal. Calcd for $\mathrm{C}_{23} \mathrm{H}_{27} \mathrm{NO} \cdot \mathrm{C}_{7} \mathrm{H}_{6} \mathrm{O}_{4} \cdot 1.25 \mathrm{H}_{2} \mathrm{O}: \mathrm{C}, 70.63 ; \mathrm{H}, 7.01 ; \mathrm{N}, 2.75$. Found: $\mathrm{C}, 70.74 ; \mathrm{H}, 6.79 ; \mathrm{N}, 2.79$.

\section{3-\{(1S,5S,6R)-5-Methyl-3-[(2E)-3-(2-methylphenyl)prop-2-en-1-yl]-3-} azabicyclo[4.1.0]hept-6-yl\}phenol Resorcylate (13)—Compound 13 was prepared in a manner analogous to that for $\mathbf{1 2}$. The free base: ${ }^{1} \mathrm{H}$ NMR (300 MHz, $\left.\mathrm{CDCl}_{3}\right) \delta 7.30-7.27$ $(\mathrm{m}, 1 \mathrm{H}), 7.05-7.01(\mathrm{~m}, 4 \mathrm{H}), 6.97(\mathrm{~d}, J=7.8 \mathrm{~Hz}, 1 \mathrm{H}), 6.70-6.61(\mathrm{~m}, 3 \mathrm{H}), 6.53(\mathrm{dd}, J=8.0$, $2.0 \mathrm{~Hz}, 1 \mathrm{H}), 6.03(\mathrm{dt}, J=9.0, \mathrm{~Hz} \mathrm{~Hz}, 1 \mathrm{H}) 3.08(\mathrm{~d}, J=6.6 \mathrm{~Hz}, 2 \mathrm{H}), 2.97$ (d, $J=11.1 \mathrm{~Hz}, 1 \mathrm{H})$, 2.66 (dd, $J=11.3,5.0 \mathrm{~Hz}, 1 \mathrm{H}), 2.53(\mathrm{dd}, J=11.4,4.5 \mathrm{~Hz}, 1 \mathrm{H}), 2.21$ (s, 3H), 2.18-2.07 (m, $1 \mathrm{H}), 1.77$ (t, $J=10.4 \mathrm{~Hz}, 1 \mathrm{H}), 1.32-1.24(\mathrm{~m}, 1 \mathrm{H}), 0.85-0.76$ (m, 2H), 0.58 (d, $J=15.9,6.6$ $\mathrm{Hz}, 3 \mathrm{H})$. The resorcylate salt: $\mathrm{mp} 152-155{ }^{\circ} \mathrm{C}[a]_{\mathrm{D}}{ }^{22}+14.75(c 0.19$, MeOH). Anal. Calcd for $\mathrm{C}_{23} \mathrm{H}_{27} \mathrm{NO} \cdot \mathrm{C}_{7} \mathrm{H}_{6} \mathrm{O}_{4} \cdot \mathrm{H}_{2} \mathrm{O}: \mathrm{C}, 71.26 ; \mathrm{H}, 6.97 ; \mathrm{N}, 2.77$. Found: $\mathrm{C}, 71.08 ; \mathrm{H}, 6.75 ; \mathrm{N}, 2.73$.

[(3-Methoxyphenyl)methylidene]hydrazine (15a)—Hydrazine hydrate (36.7 g, 0.734 mol) was added dropwise to cooled $m$-anisaldehyde (14a) $(10 \mathrm{~g}, 0.073 \mathrm{~mol})$. Ethanol (5 mL) was rinsed through the addition funnel and added to the reaction. The reaction mixture was allowed to warm to room temperature and stirred overnight. Water $(100 \mathrm{~mL})$ was added, and the product extracted with $\mathrm{CH}_{2} \mathrm{Cl}_{2}(3 \times 150 \mathrm{~mL})$. The organic layer was dried $\left(\mathrm{Na}_{2} \mathrm{SO}_{4}\right)$, 
filtered, and concentrated to afford a quantitative yield of $\mathbf{1 5 a}$ as an oil. ${ }^{1} \mathrm{H}$ NMR $(300 \mathrm{MHz}$, $\left.\mathrm{CDCl}_{3}\right) \delta 7.33(\mathrm{~s}, 1 \mathrm{H}), 7.23(\mathrm{t}, J=7 \mathrm{~Hz}, 1 \mathrm{H}), 7.16(\mathrm{~s}, 1 \mathrm{H}), 7.08(\mathrm{~d}, J=8 \mathrm{~Hz}, 1 \mathrm{H}), 6.85(\mathrm{~d}, J$ $=8 \mathrm{~Hz}, 1 \mathrm{H}), 5.53(\mathrm{~s}, 2 \mathrm{H}), 3.82(\mathrm{~s}, 3 \mathrm{H})$.

[1-(3-Methoxyphenyl)ethylidene]hydrazine (15b)-3-Methoxyacetophenone (14b) $(10 \mathrm{~g}, 0.067 \mathrm{~mol})$ was slowly added to hydrazine hydrate $(33.3 \mathrm{~g}, 0.67 \mathrm{~mol})$ at room temperature and then the solution was heated to reflux for $30 \mathrm{~min}$. Upon cooling, water (100 $\mathrm{mL})$ was added to the reaction mixture and the product was extracted with $\mathrm{CH}_{2} \mathrm{Cl}_{2}(3 \times 150$ $\mathrm{mL})$. The organic layer was dried $\left(\mathrm{Na}_{2} \mathrm{SO}_{4}\right)$, filtered, and evaporated to obtain a quantitative yield of $\mathbf{1 5 b}$ as an oil. ${ }^{1} \mathrm{H}$ NMR $\left(300 \mathrm{MHz}, \mathrm{CDCl}_{3}\right) \delta 7.23(\mathrm{~m}, 3 \mathrm{H}), 6.86(\mathrm{~m}, 1 \mathrm{H}), 5.36(\mathrm{~s}$, $2 \mathrm{H}), 3.83(\mathrm{~s}, 3 \mathrm{H}), 2.12$ (s, 3H).

(1a,5a,6a)-6-(3-Methoxyphenyl)-3-methyl-3-azabicyclo-[3.1.0]hexane-2,4-dione (16a)-Manganese dioxide (15.2 g, $0.17 \mathrm{~mol}$ ) was added to a solution of 15a (11.0 g, 0.074 $\mathrm{mol})$ in dioxane $(100 \mathrm{~mL})$. The reaction mixture was stirred for $45 \mathrm{~min}$ and then filtered through Celite and washed through with dioxane $(250 \mathrm{~mL})$. The resulting red solution was treated with 1-methyl- $1 H$-pyrrole-2,5-dione $(9.34 \mathrm{~g}, 74 \mathrm{mmol})$. The reaction mixture was stirred at room temperature for $1 \mathrm{~h}$ and then heated to reflux overnight. The reaction mixture was cooled and then concentrated. The residue was subjected to chromatography on silica gel eluting with petroleum ether/acetone (90:10) to afford $5.29 \mathrm{~g} \mathrm{(31 \% )}$ of 16a as a colorless oil. ${ }^{1} \mathrm{H}$ NMR (300 MHz, $\left.\mathrm{CDCl}_{3}\right) \delta 7.24(\mathrm{t}, J=8 \mathrm{~Hz}, 1 \mathrm{H}), 6.68(\mathrm{~d}, J=8 \mathrm{~Hz}, 1 \mathrm{H}), 6.63(\mathrm{~m}$, $2 \mathrm{H}), 3.80(\mathrm{~s}, 3 \mathrm{H}), 2.92(\mathrm{~s}, 3 \mathrm{H}), 2.76(\mathrm{~s}, 2 \mathrm{H}) ;{ }^{13} \mathrm{C} \mathrm{NMR}\left(75 \mathrm{MHz}, \mathrm{CDCl}_{3}\right) \delta 173.8,159.9$, 137.3, 130.1, 118.4, 113.2, 112.4, 55.4, 38.1, 28.9, 24.5.

\section{rac-(1 $a, 5 a, 6 a)-6$-(3-Methoxyphenyl)-1,3-dimethyl-3-}

azabicyclo[3.1.0]hexane-2,4-dione (16b)—Manganese dioxide (14.5 g, $0.17 \mathrm{~mol}$ ) was added to a solution of $\mathbf{1 5 b}(10.9 \mathrm{~g}, 0.067 \mathrm{~mol})$ in dioxane $(100 \mathrm{~mL})$. The reaction mixture was stirred for $45 \mathrm{~min}$ and then filtered through Celite and washed through with dioxane $(250 \mathrm{~mL})$. The resulting red solution was treated with 1-methyl-1 $H$-pyrrole-2,5-dione (7.33 $\mathrm{g}, 0.067 \mathrm{~mol}$ ). The reaction mixture was stirred at room temperature for $1 \mathrm{~h}$ and then heated to reflux overnight. The reaction mixture was cooled and then concentrated. The residue was subjected to chromatography on silica gel eluting with petroleum ether/acetone $(90: 10)$ to afford $3.52 \mathrm{~g}(22 \%)$ of $\mathbf{1 6 b}$ as a colorless oil. ${ }^{1} \mathrm{H}$ NMR (300 MHz, $\left.\mathrm{CDCl}_{3}\right) \delta 7.23$ (t, $J=8$ $\mathrm{Hz}, 1 \mathrm{H}), 6.90(\mathrm{~d}, J=8 \mathrm{~Hz}, 1 \mathrm{H}), 6.86(\mathrm{~m}, 2 \mathrm{H}), 3.81$ (s, 3H), 2.95 (s, 3H), 2.80 (s, 2H), 1.45 $(\mathrm{s}, 3 \mathrm{H}) ;{ }^{13} \mathrm{C} \mathrm{NMR}\left(75 \mathrm{MHz}, \mathrm{CDCl}_{3}\right) \delta 173.6,159.9,144.1,134.2,130.1,119.5,113.3,55.4$, 42.6, 32.7, 24.1, 17.6 .

\section{rac-(1a,5a,6a)-6-(3-Methoxyphenyl)-1,3,6-trimethyl-3-} azabicyclo[3.1.0]hexane-2,4-dione (16c)—Manganese dioxide (14.5 g, $0.166 \mathrm{~mol}$ ) was added to a solution of $\mathbf{1 5 b}$ (10.9 g, $0.067 \mathrm{~mol})$ in dioxane $(100 \mathrm{~mL})$. The reaction mixture was stirred for $45 \mathrm{~min}$ and then filtered through Celite and washed through with dioxane $(250 \mathrm{~mL})$. The resulting red solution was treated with 1,3-dimethyl- $1 H$-pyrrole-2,5dione $(8.41 \mathrm{~g}, 0.067 \mathrm{~mol})$. The reaction mixture was stirred at room temperature for $1 \mathrm{~h}$ and then heated to reflux overnight. The reaction mixture was cooled and then concentrated. The residue was subjected to chromatography on silica gel eluting with petroleum ether/acetone 
(90:10) to afford $6.3 \mathrm{~g} \mathrm{(37 \% )}$ of $\mathbf{1 6 c}$ as a colorless oil. ${ }^{1} \mathrm{H}$ NMR $\left(300 \mathrm{MHz}, \mathrm{CDCl}_{3}\right) \delta 7.28$ $(\mathrm{m}, 1 \mathrm{H}), 6.81(\mathrm{~m}, 3 \mathrm{H}), 3.82(\mathrm{~s}, 3 \mathrm{H}), 2.95(\mathrm{~s}, 3 \mathrm{H}), 2.68(\mathrm{~s}, \mathrm{H}), 1.42(\mathrm{~s}, 3 \mathrm{H}), 1.19(\mathrm{~s}, 3 \mathrm{H})$; LRMS (ESI, quadrupole) $\mathrm{m} / \mathrm{z} 260.4\left(\mathrm{M}+\mathrm{H}^{+}\right)$.

(1 $a, 5 a, 6 a)$-6-(3-Methoxyphenyl)-3-methyl-3-azabicyclo-[3.1.0]hexane (17a)Sodium borohydride (1.19 g, $31.6 \mathrm{mmol})$ was added in portions to a solution of $16 \mathrm{a}(3.52 \mathrm{~g}$, $0.014 \mathrm{~mol})$ in THF at $-5{ }^{\circ} \mathrm{C}$. Boron trifluoride diethyl etherate $(5.70 \mathrm{~g}, 40.1 \mathrm{mmol})$ was added dropwise to the mixture leading to the formation of a white precipitate. The reaction mixture was allowed to warm to room temperature, stirred for $2 \mathrm{~h}$, and then heated at reflux for $3 \mathrm{~h}$. The reaction mixture was cooled, treated with saturated $\mathrm{NaHCO}_{3}(150 \mathrm{~mL})$, and then extracted with EtOAc $(3 \times 150 \mathrm{~mL})$. The organic layer was dried $\left(\mathrm{Na}_{2} \mathrm{SO}_{4}\right)$, filtered, and concentrated to obtain a white solid which was subjected to chromatography on silica gel eluting with $\mathrm{CH}_{2} \mathrm{Cl}_{2}$ to obtain $2.27 \mathrm{~g}(78 \%)$ of $\mathbf{1 7 a}$ as a white solid. ${ }^{1} \mathrm{H} \mathrm{NMR}(300 \mathrm{MHz}$, $\left.\mathrm{CDCl}_{3}\right) \delta 7.15(\mathrm{t}, J=7.9 \mathrm{~Hz}, 1 \mathrm{H}), 6.68(\mathrm{ddd}, J=0.9,2.5,8.2 \mathrm{~Hz}, 1 \mathrm{H}), 6.65-6.60(\mathrm{~m}, 1 \mathrm{H})$, 6.60-6.56 (m, $1 \mathrm{H}), 3.81-3.74(\mathrm{~m}, 3 \mathrm{H}), 3.16(\mathrm{~d}, J=9.0 \mathrm{~Hz}, 2 \mathrm{H}), 2.42(\mathrm{td}, J=1.1,9.0 \mathrm{~Hz}, 2$ H), $2.36(\mathrm{~s}, 3 \mathrm{H}), 2.24(\mathrm{t}, J=3.3 \mathrm{~Hz}, 1 \mathrm{H}), 1.67(\mathrm{dt}, J=1.1,2.6 \mathrm{~Hz}, 2 \mathrm{H}) ;{ }^{13} \mathrm{C}$ NMR $(75$ $\left.\mathrm{MHz}, \mathrm{CDCl}_{3}\right) \delta 159.6,144.5,129.2,118.1,111.6,110.6,57.6,55.1,41.3,28.0,24.2$; LRMS (ESI-quadrupole) $\mathrm{m} / \mathrm{z} 204.6\left(\mathrm{M}+\mathrm{H}^{+}\right)$.

rac-(1 a,5a,6a)-6-(3-Methoxyphenyl)-1,3-dimethyl-3-azabicyclo[3.1.0]hexane (17b)-Sodium borohydride $(1.19 \mathrm{~g}, 31.6 \mathrm{mmol})$ was added in portions to a solution of $\mathbf{1 6 b}$ $(3.52 \mathrm{~g}, 0.014 \mathrm{~mol})$ in THF at $-5^{\circ} \mathrm{C}$. Boron trifluoride diethyl etherate $(5.70 \mathrm{~g}, 0.040 \mathrm{~mol})$ was added dropwise to the mixture leading to the formation of a white precipitate. The reaction mixture was allowed to warm to room temperature, stirred for $2 \mathrm{~h}$, and then heated at reflux for $3 \mathrm{~h}$. The reaction mixture was cooled, treated with saturated $\mathrm{NaHCO}_{3}(150$ $\mathrm{mL})$, and then extracted with EtOAc $(3 \times 150 \mathrm{~mL})$. The organic layer was dried $\left(\mathrm{Na}_{2} \mathrm{SO}_{4}\right)$, filtered, and concentrated to obtain a white solid which was subjected to chromatography on silica gel eluting with $\mathrm{CH}_{2} \mathrm{Cl}_{2}$ to obtain $2.27 \mathrm{~g}(78 \%)$ of $\mathbf{1 7 b}$ as a white solid. ${ }^{1} \mathrm{H}$ NMR (300 $\left.\mathrm{MHz}, \mathrm{CDCl}_{3}\right) \delta 7.23(\mathrm{t}, J=6 \mathrm{~Hz}, 1 \mathrm{H}), 6.78(\mathrm{~m}, 3 \mathrm{H}), 3.81(\mathrm{~s}, 3 \mathrm{H}), 3.59(\mathrm{~m}, 1 \mathrm{H}), 3.12(\mathrm{~m}$, $2 \mathrm{H}), 2.73(\mathrm{~m}, 3 \mathrm{H}), 2.65(\mathrm{~m}, 1 \mathrm{H}), 2.30(\mathrm{~m}, 1 \mathrm{H}), 2.23(\mathrm{~m}, 1 \mathrm{H}), 1.46(\mathrm{~s}, 2 \mathrm{H}), 1.37(\mathrm{~s}, 1 \mathrm{H})$; LRMS (ESI-quadrupole) $217.0\left(\mathrm{M}+\mathrm{H}^{+}\right)$.

rac-(1 $a, 5 a, 6 a)$-6-(3-Methoxyphenyl)-1,3,6-trimethyl-3-azabicyclo[3.1.0]hexane (17c)-Sodium borohydride ( $885 \mathrm{mg}, 23.4 \mathrm{mmol}$ ) was added in portions to a solution of $16 \mathrm{c}(2.76 \mathrm{~g}, 0.011 \mathrm{~mol})$ in THF at $-5^{\circ} \mathrm{C}$. Boron trifluoride diethyl etherate $(4.22 \mathrm{~g}, 0.03$ mol) was added dropwise to the mixture leading to the formation of a white precipitate. The reaction mixture was allowed to warm to room temperature, stirred for $2 \mathrm{~h}$, and then heated at reflux for $2 \mathrm{~h}$. The reaction mixture was cooled, treated with saturated $\mathrm{NaHCO}_{3}(150$ $\mathrm{mL})$, and then extracted with $\mathrm{CH}_{2} \mathrm{Cl}_{2}(3 \times 150 \mathrm{~mL})$. The organic layer was dried $\left(\mathrm{Na}_{2} \mathrm{SO}_{4}\right)$, filtered, and concentrated to obtain a yellow oil which was subjected to chromatography on silica gel eluting with petroleum ether/acetone (90:10) to obtain the $1.5 \mathrm{~g}(76 \%)$ of $\mathbf{1 7 c}$ as a white solid. ${ }^{1} \mathrm{H}$ NMR $\left(300 \mathrm{MHz}, \mathrm{CDCl}_{3}\right) \delta 7.23(\mathrm{t}, J=7.9 \mathrm{~Hz}, 1 \mathrm{H}), 6.82-6.68(\mathrm{~m}, 3 \mathrm{H})$, 3.80 (s, $3 \mathrm{H}), 3.37$ (d, $J=13.4 \mathrm{~Hz}, 1 \mathrm{H}), 3.28-3.13(\mathrm{~m}, 2 \mathrm{H}), 2.88$ (dd, $J=1.1,13.4 \mathrm{~Hz}, 1$ $\mathrm{H}), 2.80$ (s, $3 \mathrm{H}), 2.11-2.03(\mathrm{~m}, 1 \mathrm{H}), 1.45(\mathrm{~s}, 3 \mathrm{H}), 1.12$ (s, $3 \mathrm{H}) ;{ }^{13} \mathrm{C}$ NMR $(75 \mathrm{MHz}$, 
$\left.\mathrm{CDCl}_{3}\right) \delta 159.7,145.6,129.5,121.2,114.9,111.6,68.6,63.4,55.2,53.0,40.2,36.3,34.2$, 21.0, 18.1; LRMS (ESI-quadrupole) $232.6\left(\mathrm{M}+\mathrm{H}^{+}\right)$.

(1 a,5a,6a)-3-Benzyl-6-(3-methoxyphenyl)-6-methyl-3azabicyclo[3.1.0]hexane-2,4-dione (19a)-Manganese dioxide (7.17 g, $82.5 \mathrm{mmol}$ ) was added to a solution of $\mathbf{1 5 b}(4.95 \mathrm{~g}, 0.033 \mathrm{~mol})$ in dioxane $(80 \mathrm{~mL})$. The reaction mixture was stirred for $45 \mathrm{~min}$ and then filtered through Celite and washed through with dioxane (50 $\mathrm{mL})$. The resulting red solution was treated with $N$-benzylmaleimide (18a) $(6.17 \mathrm{~g}, 0.033$ mol). The reaction mixture was stirred at room temperature for $1 \mathrm{~h}$ and then heated to reflux overnight. The reaction mixture was cooled and then concentrated. The residue was subjected to chromatography on silica gel eluting with petroleum ether/acetone (90:10) to afford $4.15 \mathrm{~g}(39 \%)$ of 19a as a white solid. $\mathrm{Mp} 110-112{ }^{\circ} \mathrm{C}{ }^{1} \mathrm{H} \mathrm{NMR}\left(300 \mathrm{MHz}, \mathrm{CDCl}_{3}\right) \delta$ $7.43(\mathrm{dd}, J=7.7,1.7 \mathrm{~Hz}, 2 \mathrm{H}), 7.31-7.22(\mathrm{~m}, 4 \mathrm{H}), 6.86(\mathrm{dd}, J=8.0,0.8 \mathrm{~Hz}, 1 \mathrm{H}), 6.81(\mathrm{~s}$, $1 \mathrm{H}), 6.81(\mathrm{~d}, J=2.1 \mathrm{~Hz}, 1 \mathrm{H}), 4.60(\mathrm{~s}, 2 \mathrm{H}), 3.78(\mathrm{~s}, 3 \mathrm{H}), 2.76(\mathrm{~s}, 2 \mathrm{H}), 1.26(\mathrm{~s}, 3 \mathrm{H})$.

\section{rac-(1 $a, 5 a, 6 a)$-3-Benzyl-6-(3-methoxyphenyl)-1,6-dimethyl-3-} azabicyclo[3.1.0]hexane-2,4-dione (19b)—Manganese dioxide (17.36 g, $0.2 \mathrm{~mol}$ ) was added to a solution of $\mathbf{1 5 b}(10.94 \mathrm{~g}, 0.067 \mathrm{~mol})$ in dioxane $(160 \mathrm{~mL})$. The reaction mixture was stirred for $1 \mathrm{~h}$ and then filtered through Celite and washed through with dioxane (150 $\mathrm{mL}$ ). The resulting red solution was treated with 1-benzyl-3-methyl-2,5-dihydropyrrole-2,5dione $(13.39 \mathrm{~g}, 0.067 \mathrm{~mol})$. The reaction mixture was stirred at room temperature for $2 \mathrm{~h}$ and then heated at reflux for $2 \mathrm{~h}$. The reaction mixture was cooled and then concentrated under reduced pressure. The residue was subjected to chromatography on silica gel eluting with petroleum ether/acetone (90:10) to afford a 7:1 mixture of $\mathbf{1 9 b}(2.28 \mathrm{~g}, 10 \%)$ and $\mathbf{2 3}(1.82 \mathrm{~g}$, $8 \%$ ) as white semisolids. ${ }^{1} \mathrm{H}$ NMR $\left(500 \mathrm{MHz}, \mathrm{CDCl}_{3}\right) \delta 7.44(\mathrm{~d}, J=7.29 \mathrm{~Hz}, 2 \mathrm{H}), 7.20$ 7.35 (m, 4H), 6.79 (t, $J=7.55 \mathrm{~Hz}, 2 \mathrm{H}), 6.73$ (br. s., $1 \mathrm{H}), 4.54-4.68(\mathrm{~m}, 2 \mathrm{H}), 3.79$ (s, 3H), $2.65(\mathrm{~s}, 1 \mathrm{H}), 1.23(\mathrm{~s}, 3 \mathrm{H}), 1.16(\mathrm{~s}, 3 \mathrm{H}) ;{ }^{13} \mathrm{C} \mathrm{NMR}\left(75 \mathrm{MHz}, \mathrm{CDCl}_{3}\right) \delta 177.0,174.3,160.3$, $142.4,136.1,130.4,129.7,129.0,128.4,120.8,114.3,113.3,55.7,46.1,42.5,37.0,35.3$, 19.0, 12.5.

(1 $a, 5 a, 6 a)$-3-Benzyl-6-(3-methoxyphenyl)-6-methyl-3-azabicyclo[3.1.0]hexane (20a)-Sodium borohydride $(0.26 \mathrm{~g}, 6.9 \mathrm{mmol})$ was added in portions to a solution of 19a $(1.05 \mathrm{~g}, 0.0033 \mathrm{~mol})$ in THF at $-10^{\circ} \mathrm{C}$. Boron trifluoride diethyl etherate $(1.30 \mathrm{~g}, 0.0092$ mol) was added dropwise, and the reaction mixture was allowed to warm to room temperature, stirred for $2 \mathrm{~h}$, and then heated at reflux for $3 \mathrm{~h}$. The reaction mixture was cooled, treated with an aqueous solution of piperazine hydrate $\left(1.7 \mathrm{~g}, 19.6 \mathrm{mmol}\right.$ ) in $\mathrm{H}_{2} \mathrm{O}$ $(12 \mathrm{~mL})$, and then heated at reflux for $18 \mathrm{~h}$. The solution was cooled to room temperature and extracted with EtOAc $(3 \times 50 \mathrm{~mL})$. The organic extracts were combined, dried $\left(\mathrm{Na}_{2} \mathrm{SO}_{4}\right)$, and concentrated under reduced pressure to obtain a pale yellow oil which was subjected to chromatography on silica gel eluting with petroleum ether/acetone (95:5) to obtain the $0.69 \mathrm{~g}(72 \%)$ of $\mathbf{2 0 a}$ as a colorless oil. ${ }^{1} \mathrm{H}$ NMR (300 MHz, $\left.\mathrm{CDCl}_{3}\right) \delta 7.33-7.08$ $(\mathrm{m}, 6 \mathrm{H}), 6.82-6.79(\mathrm{~m}, 2 \mathrm{H}), 6.68-6.64(\mathrm{~m}, 1 \mathrm{H}), 3.73(\mathrm{~s}, 3 \mathrm{H}), 3.63(\mathrm{~s}, 2 \mathrm{H}), 3.02(\mathrm{~d}, J=9.3$ $\mathrm{Hz}, 2 \mathrm{H}), 2.82-2.73(\mathrm{~m}, 2 \mathrm{H}), 1.72$ (s, 2H), 1.61 (s, 3H). 
rac-(1 $a, 5 a, 6 a)$-3-Benzyl-6-(3-methoxyphenyl)-1,6-dimethyl-3-

azabicyclo[3.1.0]hexane (20b)—Sodium borohydride ( $0.54 \mathrm{~g}, 14.3 \mathrm{mmol})$ was added in portions to a solution of $\mathbf{1 9 b}(2.28 \mathrm{~g}, 0.0068 \mathrm{~mol})$ in $\mathrm{THF}(150 \mathrm{~mL})$ at $-10{ }^{\circ} \mathrm{C}$. Boron trifluoride diethyl etherate $(2.70 \mathrm{~g}, 19.04 \mathrm{mmol})$ was added dropwise, and reaction mixture was allowed to warm to room temperature, stirred for $2 \mathrm{~h}$, and then heated at reflux for $3 \mathrm{~h}$. The reaction mixture was cooled, treated with an aqueous solution of piperazine hydrate ( 3.4 $\mathrm{g}, 0.039 \mathrm{~mol})$ in $\mathrm{H}_{2} \mathrm{O}(25 \mathrm{~mL})$, and then heated at reflux for $12 \mathrm{~h}$. The solution was cooled to room temperature, diluted with $\mathrm{H}_{2} \mathrm{O}(200 \mathrm{~mL})$, and extracted with EtOAc $(3 \times 150 \mathrm{~mL})$. The organic layer was dried $\left(\mathrm{MgSO}_{4}\right)$, filtered, and concentrated under reduced pressure to obtain a pale yellow oil which was subjected to chromatography on silica gel eluting with petroleum ether/acetone (95:5) to obtain the $1.51 \mathrm{~g}(72 \%)$ of $\mathbf{2 0 b}$ as a colorless oil. ${ }^{1} \mathrm{H}$ NMR (300 MHz, $\left.\mathrm{CDCl}_{3}\right) \delta 7.35-7.12(\mathrm{~m}, 6 \mathrm{H}), 6.82-6.65(\mathrm{~m}, 3 \mathrm{H}), 3.78(\mathrm{~s}, 3 \mathrm{H}), 3.73-3.59(\mathrm{~m}$, 2H), $3.07(\mathrm{dd}, J=3.0,9.4 \mathrm{~Hz}, 2 \mathrm{H}), 2.91(\mathrm{dd}, J=4.9,9.4 \mathrm{~Hz}, 1 \mathrm{H}), 2.60(\mathrm{~d}, J=9.4 \mathrm{~Hz}, 1 \mathrm{H})$, $1.61(\mathrm{~s}, 3 \mathrm{H}), 1.57$ (d, $J=4.9 \mathrm{~Hz}, 1 \mathrm{H}), 0.91(\mathrm{~s}, 3 \mathrm{H})$.

\section{3-[(1a,5a,6a)-3-Benzyl-6-methyl-3-azabicyclo[3.1.0]hex-6-yl]phenol (21a)-A}

$1.0 \mathrm{M}$ solution of boron trichloride in $\mathrm{CH}_{2} \mathrm{Cl}_{2}(10.57 \mathrm{~mL}, 10.57 \mathrm{mmol})$ was added dropwise to a solution of tetrabutylammonium iodide (2.17 g, $0.0059 \mathrm{~mol}), \mathbf{2 0 a}(690 \mathrm{mg}, 2.35 \mathrm{mmol})$ in $\mathrm{CH}_{2} \mathrm{Cl}_{2}(15 \mathrm{~mL})$. The mixture was allowed to warm to room temperature and stirred for 2 h. Ice and water $(50 \mathrm{~mL})$ were added to quench the reaction, and the biphasic mixture was allowed to stir for $30 \mathrm{~min}$ and was extracted with $\mathrm{CH}_{2} \mathrm{Cl}_{2}(3 \times 50 \mathrm{~mL})$. The extracts were combined, dried $\left(\mathrm{MgSO}_{4}\right)$, and concentrated under reduced pressure to afford an oil. The oil was purified using silica gel chromatography with petroleum ether and acetone (9:1) as eluents to afford 21a $(0.62 \mathrm{~g}, 94 \%)$ as a colorless semisolid. ${ }^{1} \mathrm{H} \mathrm{NMR}\left(300 \mathrm{MHz}, \mathrm{CDCl}_{3}\right) \delta$ 7.86 (br. s, 1H), 7.35-7.20 (m 5H), $7.04(\mathrm{t}, J=7.8 \mathrm{~Hz}, 1 \mathrm{H}), 6.71(\mathrm{~d}, J=7.8 \mathrm{~Hz}, 1 \mathrm{H}), 6.64$ $6.57(\mathrm{~m}, 2 \mathrm{H}), 3.66(\mathrm{~s}, 2 \mathrm{H}), 3.03-2.91(\mathrm{~m}, 2 \mathrm{H}), 2.78(\mathrm{~d}, J=10.2 \mathrm{~Hz}, 2 \mathrm{H}), 1.75(\mathrm{~s}, 2 \mathrm{H}), 1.41$ (s, 3H); ${ }^{13} \mathrm{C}-\mathrm{DEPT} 135 \mathrm{NMR}\left(75 \mathrm{MHz}, \mathrm{CDCl}_{3}\right) \delta 129.8(\mathrm{CH}), 129.3(\mathrm{CH}), 128.8(\mathrm{CH})$, $127.5(\mathrm{CH}), 119.1(\mathrm{CH}), 114.8(\mathrm{CH}), 113.7(\mathrm{CH}), 59.5\left(\mathrm{CH}_{2}\right), 53.5\left(\mathrm{CH}_{2}\right), 31.0(\mathrm{CH}), 15.18$ $\left(\mathrm{CH}_{3}\right)$.

rac-3-[(1 $a, 5 a, 6 a)$-3-Benzyl-1,6-dimethyl-3-azabicyclo[3.1.0]-hex-6-yl]phenol (21b)-A $1.0 \mathrm{M}$ solution of boron trichloride in $\mathrm{CH}_{2} \mathrm{Cl}_{2}(22 \mathrm{~mL}, 22 \mathrm{mmol})$ was added dropwise to a solution of tetrabutylammonium iodide ( $4.53 \mathrm{~g}, 0.0123 \mathrm{~mol}), 20 \mathrm{~b}(1.51 \mathrm{~g}$, $0.0049 \mathrm{~mol})$ in $\mathrm{CH}_{2} \mathrm{Cl}_{2}(30 \mathrm{~mL})$. The mixture was allowed to warm to room temperature and stirred for $2 \mathrm{~h}$. Ice and water $(75 \mathrm{~mL})$ were added to quench the reaction, and the biphasic mixture was allowed to stir for $30 \mathrm{~min}$ and was extracted with $\mathrm{CH}_{2} \mathrm{Cl}_{2}(3 \times 75 \mathrm{~mL})$. The extracts were combined, dried $\left(\mathrm{MgSO}_{4}\right)$, and concentrated under reduced pressure to afford an oil. The oil was purified using silica gel chromatography with petroleum ether and acetone (9:1) as eluents to afford $\mathbf{2 1 b}(1.36 \mathrm{~g}, 94 \%)$ as a colorless semisolid. ${ }^{1} \mathrm{H}$ NMR (300 $\left.\mathrm{MHz}, \mathrm{CDCl}_{3}\right) \delta 7.33-7.21(\mathrm{~m}, 5 \mathrm{H}), 7.06(\mathrm{t}, J=8.1 \mathrm{~Hz}, 1 \mathrm{H}), 6.67(\mathrm{~d}, J=7.8 \mathrm{~Hz}, 1 \mathrm{H}), 6.60$ (s, 1H), $6.59(\mathrm{~d}, J=6.3 \mathrm{~Hz}, 1 \mathrm{H}), 3.72-3.62(\mathrm{~m}, 2 \mathrm{H}), 3.09-3.03(\mathrm{~m}, 1 \mathrm{H}), 2.88(\mathrm{~d}, J=9.9 \mathrm{~Hz}$, $1 \mathrm{H}), 2.84(\mathrm{~d}, J=9.9 \mathrm{~Hz}, 1 \mathrm{H}), 2.73(\mathrm{~d}, J=9.9 \mathrm{~Hz}, 1 \mathrm{H}), 1.56(\mathrm{~d}, J=4.8 \mathrm{~Hz}, 1 \mathrm{H}), 1.31$ (s, 3H), $0.85(\mathrm{~s}, 3 \mathrm{H})$. 


\section{3-[(1 $a, 5 a, 6 a)$-3-Benzyl-6-methyl-3-azabicyclo[3.1.0]hex-6-yl]phenyl Acetate} (22a)-Sodium hydroxide (180 mg, $4.47 \mathrm{mmol})$ was added to a solution of $21 \mathrm{a}(1.25 \mathrm{~g}$, $0.0045 \mathrm{~mol})$ and tetrabutylammonium sulfate $(0.015 \mathrm{~g})$ in dioxane at $0{ }^{\circ} \mathrm{C}$ and allowed to stir for $1 \mathrm{~h}$. Acetyl chloride $(0.42 \mathrm{~g}, 5.36 \mathrm{mmol})$ was then added dropwise, and the reaction was allowed to warm to room temperature over $4 \mathrm{~h}$. The solution was diluted with $\mathrm{H}_{2} \mathrm{O}(50 \mathrm{~mL})$ and extracted with $\mathrm{CH}_{2} \mathrm{Cl}_{2}(3 \times 50 \mathrm{~mL})$. The extracts were combined, dried $\left(\mathrm{MgSO}_{4}\right)$, and concentrated under reduced pressure to afford an oil. The oil was purified using silica gel chromatography eluting with petroleum ether/acetone (90:10) to obtain 22a $(0.86 \mathrm{~g}, 60 \%)$ as a colorless oil. ${ }^{1} \mathrm{H}$ NMR $\left(300 \mathrm{MHz}, \mathrm{CDCl}_{3}\right) \delta 7.29-7.18(\mathrm{~m} 6 \mathrm{H}), 7.05(\mathrm{~d}, J=7.8 \mathrm{~Hz}, 1 \mathrm{H})$, $6.86(\mathrm{~s}, 1 \mathrm{H}), 7.03(\mathrm{~d}, J=7.8 \mathrm{~Hz}, 1 \mathrm{H}), 3.63(\mathrm{~s}, 2 \mathrm{H}), 3.02(\mathrm{~d}, J=9.9 \mathrm{~Hz}, 2 \mathrm{H}), 2.82-2.72(\mathrm{~m}$, $2 \mathrm{H}), 2.21(\mathrm{~s}, 3 \mathrm{H}), 1.75-1.67(\mathrm{~m}, 2 \mathrm{H}), 1.61(\mathrm{~s}, 3 \mathrm{H})$.

rac-3-[(1 $a, 5 a, 6 a)$-3-Benzyl-1,6-dimethyl-3-azabicyclo[3.1.0]-hex-6-yl]phenyl Acetate (22b)-A solution of $\mathbf{2 1 b}(1.36 \mathrm{~g}, 0.0046 \mathrm{~mol})$ in THF (20 mL) was added to a solution of $\mathrm{NaH}(60 \%, 210 \mathrm{mg}, 5.34 \mathrm{mmol})$ in THF $(50 \mathrm{~mL})$ at $0{ }^{\circ} \mathrm{C}$ under $\mathrm{N}_{2}$. The suspension was allowed to stir at $0{ }^{\circ} \mathrm{C}$ for $1 \mathrm{~h}$. Acetyl chloride $(420 \mathrm{mg}, 5.34 \mathrm{mmol}$ ) was then added dropwise, and the solution was allowed to warm to room temperature. The solution was diluted with $\mathrm{H}_{2} \mathrm{O}(50 \mathrm{~mL})$ and extracted with $\mathrm{CH}_{2} \mathrm{Cl}_{2}(3 \times 50 \mathrm{~mL})$. The organic extracts were combined, dried $\left(\mathrm{MgSO}_{4}\right)$, and concentrated under reduced pressure to afford an oil that was purified on silica gel eluting with petroleum ether/acetone (95:5) to obtain 22b $(1.12 \mathrm{~g}, 72 \%)$ as a colorless oil. ${ }^{1} \mathrm{H}$ NMR $\left(300 \mathrm{MHz}, \mathrm{CDCl}_{3}\right) \delta 7.31-7.17(\mathrm{~m}, 6 \mathrm{H}), 7.05$ $(\mathrm{d}, J=7.8 \mathrm{~Hz}, 1 \mathrm{H}), 6.91-6.84(\mathrm{~m}, 2 \mathrm{H}), 3.79-3.60(\mathrm{~m}, 2 \mathrm{H}), 3.06(\mathrm{dd}, J=9.5,3.2 \mathrm{~Hz}, 2 \mathrm{H})$, $2.90(\mathrm{dd}, J=9.5,5.0 \mathrm{~Hz}, 1 \mathrm{H}), 2.60(\mathrm{~d}, J=9.6 \mathrm{~Hz}, 1 \mathrm{H}), 2.27(\mathrm{~s}, 3 \mathrm{H}), 1.62(\mathrm{~s}, 3 \mathrm{H}), 1.56(\mathrm{~d}, J$ $=4.8 \mathrm{~Hz}, 1 \mathrm{H}), 0.91(\mathrm{~s}, 3 \mathrm{H})$.

rac-3-[(1 $a, 5 a, 6 \beta)$-3-Benzyl-6-(3-methoxyphenyl)-1,6-di-methyl-3azabicyclo[3.1.0]hexane-2,4-dione (23)-Manganese dioxide (17.36 g, $0.2 \mathrm{~mol}$ ) was added to a solution of $15 \mathrm{~b}(10.94 \mathrm{~g}, 0.067 \mathrm{~mol})$ in dioxane $(160 \mathrm{~mL})$. The reaction mixture was stirred for $1 \mathrm{~h}$ and then filtered through Celite and washed through with dioxane (150 $\mathrm{mL}$ ). The resulting red solution was treated with 1-benzyl-3-methyl-2,5-dihydropyrrole-2,5dione $(13.39 \mathrm{~g}, 0.067 \mathrm{~mol})$. The reaction mixture was stirred at room temperature for $2 \mathrm{~h}$ and then heated at reflux for $2 \mathrm{~h}$. The reaction mixture was cooled and then concentrated under reduced pressure. The residue was subjected to chromatography on silica gel eluting with petroleum ether/acetone (90:10) to afford a 7:1 mixture of $\mathbf{1 9 b}(2.28 \mathrm{~g}, 10 \%)$ and $\mathbf{2 3}(1.82 \mathrm{~g}$, $8 \%)$ as white semisolids. ${ }^{1} \mathrm{H}$ NMR $\left(300 \mathrm{MHz}, \mathrm{CDCl}_{3}\right) \delta 7.12-7.05(\mathrm{~m}, 3 \mathrm{H}), 7.01(\mathrm{t}, J=7.9$ $\mathrm{Hz}, 1 \mathrm{H}), 6.94-6.84(\mathrm{~m}, 2 \mathrm{H}), 6.74(\mathrm{~d}, J=7.5 \mathrm{~Hz}, 1 \mathrm{H}), 6.64(\mathrm{~s}, 1 \mathrm{H}), 6.61-6.54(\mathrm{~m}, 1 \mathrm{H}), 4.04$ (s, 2H), $3.64(\mathrm{~s}, 3 \mathrm{H}), 2.32(\mathrm{~s}, 1 \mathrm{H}), 1.64(\mathrm{~s}, 3 \mathrm{H}), 1.43$ (s, 3H)

rac-3-[(1 $a, 5 a, 6 \beta)-3-B e n z y l-6-(3-m e t h o x y p h e n y l)-1,6-d i-m e t h y l-3-$ azabicyclo[3.1.0]hexane (24a)—Sodium borohydride (430 mg, $11.4 \mathrm{mmol}$ ) was added in portions to a solution of $23(1.82 \mathrm{~g}, 0.0054 \mathrm{~mol})$ in THF $(100 \mathrm{~mL})$ at $-10{ }^{\circ} \mathrm{C}$. Boron trifluoride diethyl etherate $(2.15 \mathrm{~g}, 0.015 \mathrm{~mol})$ was added dropwise, and the reaction mixture was allowed to warm to room temperature, stirred for $2 \mathrm{~h}$, and then heated at reflux for $3 \mathrm{~h}$. The reaction mixture was cooled, treated with an aqueous solution of piperazine hydrate (2.68 g, $0.031 \mathrm{~mol})$ in $\mathrm{H}_{2} \mathrm{O}(20 \mathrm{~mL})$, and then heated at reflux for $12 \mathrm{~h}$. The solution was 
cooled to room temperature, diluted with $\mathrm{H}_{2} \mathrm{O}(200 \mathrm{~mL})$, and extracted with EtOAc $(3 \times 100$ $\mathrm{mL})$. The organic layer was dried $\left(\mathrm{MgSO}_{4}\right)$, filtered, and concentrated to obtain a pale yellow oil which was subjected to chromatography on silica gel eluting with petroleum ether/acetone (95:5) to obtain $\mathbf{2 4 a}(0.91 \mathrm{~g}, 55 \%)$ as a colorless oil. ${ }^{1} \mathrm{H}$ NMR $(300 \mathrm{MHz}$, $\left.\mathrm{CDCl}_{3}\right) \delta 7.23(\mathrm{t}, J=7.7 \mathrm{~Hz}, 1 \mathrm{H}), 7.09-7.00(\mathrm{~m}, 3 \mathrm{H}), 6.81(\mathrm{dd}, J=2.6,8.3 \mathrm{~Hz}, 1 \mathrm{H}), 6.75(\mathrm{~d}$, $J=7.5 \mathrm{~Hz}, 1 \mathrm{H}), 6.67(\mathrm{~d}, J=1.9 \mathrm{~Hz}, 1 \mathrm{H}), 6.51-6.40(\mathrm{~m}, 2 \mathrm{H}), 3.77$ (s, 3H), $3.24(\mathrm{q}, J=13.6$ $\mathrm{Hz}, 2 \mathrm{H}), 2.95-2.77(\mathrm{~m}, 2 \mathrm{H}), 2.50(\mathrm{dd}, J=4.0,8.9 \mathrm{~Hz}, 1 \mathrm{H}), 2.26(\mathrm{~d}, J=9.0 \mathrm{~Hz}, 1 \mathrm{H}), 1.36$ (s, $3 \mathrm{H}), 1.26(\mathrm{~s}, 3 \mathrm{H}), 1.12(\mathrm{~d}, J=3.8 \mathrm{~Hz}, 1 \mathrm{H})$

rac-3-[(1 $a, 5 a, 6 \beta)$-3-Benzyl-1,6-dimethyl-3-azabicyclo[3.1.0]-hex-6-yl]phenol (24b) - A $1.0 \mathrm{M}$ solution of boron trichloride in $\mathrm{CH}_{2} \mathrm{Cl}_{2}(12 \mathrm{~mL}, 12 \mathrm{mmol})$ was added dropwise to a solution of tetrabutylammonium iodide $(2.47 \mathrm{~g}, 0.0067 \mathrm{~mol})$ and $24 \mathbf{a}(820 \mathrm{mg}$, $2.68 \mathrm{mmol})$ in $\mathrm{CH}_{2} \mathrm{Cl}_{2}(20 \mathrm{~mL})$. The mixture was allowed to warm to room temperature and stirred for $2 \mathrm{~h}$. Ice and water $(50 \mathrm{~mL})$ were added to quench the reaction, and the biphasic mixture was allowed to stir for $30 \mathrm{~min}$ and was extracted with $\mathrm{CH}_{2} \mathrm{Cl}_{2}(3 \times 50 \mathrm{~mL})$. The extracts were combined, dried $\left(\mathrm{MgSO}_{4}\right)$, and concentrated under reduced pressure to afford an oil. The oil was purified using silica gel chromatography with petroleum ether and acetone (9:1) as eluents to afford $\mathbf{2 4 b}(0.23 \mathrm{~g}, 30 \%)$ as a colorless semisolid. ${ }^{1} \mathrm{H}$ NMR (300 $\left.\mathrm{MHz}, \mathrm{CDCl}_{3}\right) \delta 7.15(\mathrm{t}, J=7.7 \mathrm{~Hz}, 1 \mathrm{H}), 7.10-7.01(\mathrm{~m}, 3 \mathrm{H}), 6.73(\mathrm{dd}, J=1.9,7.9 \mathrm{~Hz}, 1 \mathrm{H})$, 6.68 (d, $J=7.5 \mathrm{~Hz}, 1 \mathrm{H}), 6.60$ (br. s., $1 \mathrm{H}), 6.53$ (d, $J=3.0 \mathrm{~Hz}, 2 \mathrm{H}), 3.33-3.12(\mathrm{~m}, 2 \mathrm{H}), 2.93-$ $2.73(\mathrm{~m}, 2 \mathrm{H}), 2.61(\mathrm{~s}, 1 \mathrm{H}), 2.54(\mathrm{dd}, J=3.8,9.0 \mathrm{~Hz}, 1 \mathrm{H}), 2.29(\mathrm{~d}, J=9.0 \mathrm{~Hz}, 1 \mathrm{H}), 1.38-$ $1.29(\mathrm{~m}, 3 \mathrm{H}), 1.26(\mathrm{~s}, 3 \mathrm{H}), 1.10(\mathrm{~d}, J=3.8 \mathrm{~Hz}, 1 \mathrm{H})$.

rac-3-[(1 $a, 5 a, 6 \beta)$-3-Benzyl-1,6-dimethyl-3-azabicyclo[3.1.0]-hex-6-yl]phenol Methanesulfonate (24c)-Methanesulfonyl chloride (110 mg, $0.94 \mathrm{mmol}$ ) was added to a solution of $\mathbf{2 4 \mathbf { b }}(230 \mathrm{mg}, 0.78 \mathrm{mmol})$ in pyridine $(10 \mathrm{~mL})$ at $0{ }^{\circ} \mathrm{C}$. The solution was allowed to warm to room temperature over $2 \mathrm{~h}$, and $\mathrm{H}_{2} \mathrm{O}(10 \mathrm{~mL})$ was added. The biphasic mixture was extracted with $\mathrm{CH}_{2} \mathrm{Cl}_{2}(3 \times 25 \mathrm{~mL})$, and the organic extracts were combined, dried $\left(\mathrm{MgSO}_{4}\right)$, and concentrated under reduced pressure to afford an oil. The oil was purified on silica gel eluting with petroleum ether/acetone (95:5) to obtain $\mathbf{2 4 c}(0.18 \mathrm{~g}, 60 \%)$ as a colorless oil. ${ }^{1} \mathrm{H}$ NMR $\left(300 \mathrm{MHz}, \mathrm{CDCl}_{3}\right) \delta 7.42-7.28(\mathrm{~m}, 1 \mathrm{H}), 7.22-7.14(\mathrm{~m}, 1 \mathrm{H})$, 7.13-7.00 (m, 5H), 6.46-6.35 (m, 2H), 3.28 (d, $J=13.6 \mathrm{~Hz}, 1 \mathrm{H}), 3.17$ (d, $J=13.6 \mathrm{~Hz}, 1 \mathrm{H})$, $2.98(\mathrm{~s}, 3 \mathrm{H}), 2.89$ (d, $J=9.4 \mathrm{~Hz}, 1 \mathrm{H}), 2.76(\mathrm{~d}, J=9.0 \mathrm{~Hz}, 1 \mathrm{H}), 2.53(\mathrm{dd}, J=3.8,9.4 \mathrm{~Hz}$, $1 \mathrm{H}), 2.27(\mathrm{~d}, J=9.4 \mathrm{~Hz}, 1 \mathrm{H}), 1.37$ (s, 3H), $1.26(\mathrm{~s}, 3 \mathrm{H}), 1.17$ (d, $J=3.4 \mathrm{~Hz}, 1 \mathrm{H})$.

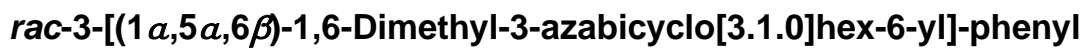
Methanesulfonate (24d)_A solution of $\mathbf{2 4 c}(170 \mathrm{mg}, 0.47 \mathrm{mmol})$ in EtOH $(20 \mathrm{~mL})$ was added to a Parr hydrogenation bottle under $\mathrm{N}_{2}$. Solid $10 \% \mathrm{Pd} / \mathrm{C}(0.15 \mathrm{~g})$ was added followed by a $1.0 \mathrm{M}$ solution of $\mathrm{HCl}$ in $\mathrm{Et}_{2} \mathrm{O}(0.47 \mathrm{~mL}, 0.47 \mathrm{mmol})$, and the solution was hydrogenated at $40 \mathrm{psi}$ for $8 \mathrm{~h}$. The solution was then filtered through a pad of Celite and concentrated under reduced pressure to afford $\mathbf{2 4 d}(0.18 \mathrm{~g}, 88 \%)$ as a colorless oil. ${ }^{1} \mathrm{H}$ NMR $\left(300 \mathrm{MHz}, \mathrm{CDCl}_{3}\right) \delta 7.38(\mathrm{t}, J=6.0 \mathrm{~Hz}, 1 \mathrm{H}), 7.23-7.06(\mathrm{~m}, 3 \mathrm{H}), 3.13(\mathrm{~s}, 3 \mathrm{H}), 3.02(\mathrm{~d}, J=$ $12 \mathrm{~Hz}, 1 \mathrm{H}), 2.91-2.76(\mathrm{~m}, 3 \mathrm{H}), 1.41(\mathrm{~s}, 3 \mathrm{H}), 1.26(\mathrm{~s}, 3 \mathrm{H}), 1.22$ (d, $J=3 \mathrm{~Hz}, 1 \mathrm{H})$.

J Org Chem. Author manuscript; available in PMC 2017 September 06. 
rac-3-[(1 $a, 5 a, 6 \beta)$-1,6-Dimethyl-3-[(2E)-3-(2-methylphenyl)-prop-2-en-1-yl]-3azabicyclo[3.1.0]hex-6-yl\}phenyl Methane-sulfonate (24e)-A solution of trans-2methylcinnamaldehyde $(70 \mathrm{mg}, 0.50 \mathrm{mmol})$ in 1,2-dichloroethane $(10 \mathrm{~mL})$ was then added to a suspension of $\mathbf{2 4 d}(120 \mathrm{mg}, 0.42 \mathrm{mmol})$ and sodium triacetoxyborohydride (140 $\mathrm{mg}$, $0.63 \mathrm{mmol})$ in 1,2-dichloroethane $(10 \mathrm{~mL})$. The suspension was allowed to stir at room temperature for $4 \mathrm{~h}$ and was diluted with a saturated solution of $\mathrm{NaHCO}_{3}(10 \mathrm{~mL})$ and extracted with $\mathrm{CH}_{2} \mathrm{Cl}_{2}(3 \times 20 \mathrm{~mL})$. The resulting extracts were combined, dried $\left(\mathrm{MgSO}_{4}\right)$, and concentrated under reduced pressure to afford an oil that was purified using silica gel chromatography $\left(\mathrm{CHCl}_{3}, \mathrm{MeOH}, \mathrm{NH}_{4} \mathrm{OH} ; 90: 9: 1\right)$ to provide $24 \mathrm{e}(0.11 \mathrm{~g}, 65 \%)$ as a colorless oil. ${ }^{1} \mathrm{H}$ NMR $\left(300 \mathrm{MHz}, \mathrm{CDCl}_{3}\right) \delta 7.36-6.99(\mathrm{~m}, 8 \mathrm{H}), 6.32(\mathrm{~d}, J=15.8 \mathrm{~Hz}, 1 \mathrm{H})$, $5.36(\mathrm{td}, J=6.4,15.4 \mathrm{~Hz}, 1 \mathrm{H}), 2.97-2.76(\mathrm{~m}, 7 \mathrm{H}), 2.53(\mathrm{dd}, J=3.6,9.2 \mathrm{~Hz}, 1 \mathrm{H}), 2.33(\mathrm{~d}, J$ $=9.4 \mathrm{~Hz}, 1 \mathrm{H}), 2.24(\mathrm{~s}, 3 \mathrm{H}), 1.39(\mathrm{~s}, 3 \mathrm{H}), 1.31-1.22(\mathrm{~m}, 3 \mathrm{H}), 1.19-1.12(\mathrm{~m}, 1 \mathrm{H})$.

(3R)-3-Methyl-4-[3-(1-methylethoxy)phenyl]-1,2,3,6-tetrahydropyridine (25b)1-Chloroethyl chloroformate $(29.13 \mathrm{~g}, 0.2 \mathrm{~mol})$ was added to a solution of $\mathbf{2 5 \mathbf { a } ^ { 1 5 }}(10 \mathrm{~g}$, $0.041 \mathrm{~mol})$ in 1,2-dichloroethane $(150 \mathrm{~mL}$ ) and heated at reflux for $48 \mathrm{~h}$. The solution was allowed to cool to room temperature, $\mathrm{MeOH}(150 \mathrm{~mL})$ was added, and the mixture was again heated at reflux for $48 \mathrm{~h}$. The solution was cooled, made basic with saturated $\mathrm{NaHCO}_{3}$, and extracted with $\mathrm{CH}_{2} \mathrm{Cl}_{2}(3 \times 75 \mathrm{~mL})$. The extracts were combined, dried $\left(\mathrm{MgSO}_{4}\right)$, and concentrated under reduced pressure to afford an oil that was purified using silica gel chromatography $\left(\mathrm{CHCl}_{3}, \mathrm{MeOH}, \mathrm{NH}_{4} \mathrm{OH} ; 80: 18: 2\right)$ to provide $25 \mathrm{~b}(7.92 \mathrm{~g}, 84 \%)$ as a colorless oil. ${ }^{1} \mathrm{H}$ NMR $\left(300 \mathrm{MHz}, \mathrm{CDCl}_{3}\right) \delta 7.21(\mathrm{t}, J=8.0 \mathrm{~Hz}, 1 \mathrm{H}), 6.89-6.84(\mathrm{~m}$, $2 \mathrm{H}$ ), 6.77 (dd, $J=8.1,2.4 \mathrm{~Hz}, 1 \mathrm{H}$ ), 5.92 (t, $J=3.3 \mathrm{~Hz}, 1 \mathrm{H}$ ), 4.55 (sept., $J=6.0 \mathrm{~Hz}, 1 \mathrm{H}$ ), $3.52-3.38(\mathrm{~m}, 2 \mathrm{H}), 3.13(\mathrm{dd}, J=12.5,4.7 \mathrm{~Hz}, 1 \mathrm{H}), 2.83$ (dd, $J=12.3,4.2 \mathrm{~Hz}, 1 \mathrm{H}), 2.72$ (br. s, 1H), 1.59 (br. s, 1H), 1.34 (dd, $J=6.0,2.1 \mathrm{~Hz}, 6 \mathrm{H}), 0.99$ (d, $J=6.9 \mathrm{~Hz}, 3 \mathrm{H})$.

(3R)-3-Methyl-4-[3-(1-methylethoxy)phenyl]-1-[(trifluoromethyl)sulfonyl]-1,2,3,6-tetrahydropyridine (25c)-Trifluoro-methanesulfonic acid anhydride (11.60 g, $0.041 \mathrm{~mol}$ ) was added dropwise to a solution of $\mathbf{2 5 \mathbf { b }}(7.92 \mathrm{~g}, 0.034 \mathrm{~mol})$ and TEA ( $4.16 \mathrm{~g}, 41.07 \mathrm{mmol})$ in $\mathrm{CH}_{2} \mathrm{Cl}_{2}(150 \mathrm{~mL})$ at $-78^{\circ} \mathrm{C}$ under $\mathrm{N}_{2}$. The solution was allowed to stir at $-78{ }^{\circ} \mathrm{C}$ for $2 \mathrm{~h}$ and then allowed to warm to room temperature. The solution was then made acidic with $1 \mathrm{M} \mathrm{HCl}$ and extracted with $\mathrm{CH}_{2} \mathrm{Cl}_{2}(3 \times 100 \mathrm{~mL})$. The extracts were combined, dried $\left(\mathrm{MgSO}_{4}\right)$, and concentrated under reduced pressure to provide an oil. The oil was purified on silica gel using petroleum ether and acetone (9.5:0.5) as eluents to afford $25 \mathrm{c}(9.08 \mathrm{~g}, 73 \%)$ as a colorless oil. ${ }^{1} \mathrm{H} \mathrm{NMR}\left(300 \mathrm{MHz}, \mathrm{CDCl}_{3}\right) \delta 7.25(\mathrm{t}$, $J=8.4 \mathrm{~Hz}, 1 \mathrm{H}), 6.88-6.82(\mathrm{~m}, 3 \mathrm{H}), 5.83(\mathrm{t}, J=3.2 \mathrm{~Hz}, 1 \mathrm{H}), 4.57$ (sept., $J=6.2 \mathrm{~Hz}, 1 \mathrm{H}$ ), $4.24(\mathrm{~d}, J=17.1 \mathrm{~Hz}, 1 \mathrm{H}), 4.02$ (d, $J=17.4 \mathrm{~Hz}, 1 \mathrm{H}), 3.69-3.42(\mathrm{~m}, 2 \mathrm{H}), 2.94$ (br. s, $1 \mathrm{H})$, $1.34(\mathrm{dd}, J=6.0,2.1 \mathrm{~Hz}, 6 \mathrm{H}), 1.09(\mathrm{~d}, J=6.9 \mathrm{~Hz}, 3 \mathrm{H})$.

(1R,5R,6R)-7,7-Dibromo-5-methyl-6-[3-(1-methylethoxy)-phenyl]-3[(trifluoromethyl)sulfonyl]-3-azabicyclo[4.1.0]-heptane (26)—Sodium hydroxide (50\% aqueous, $12.5 \mathrm{~mL}$ ) was added dropwise to a solution of $25 \mathrm{c}(9.08 \mathrm{~g}, 0.025 \mathrm{~mol})$, $\mathrm{CHBr}_{3}$ (13.54 g, $0.05 \mathrm{~mol}$ ), benzyltrimethylammonium chloride (125 mg, $0.55 \mathrm{mmol}$ ), and EtOH $(0.10 \mathrm{~mL})$, in $\mathrm{CH}_{2} \mathrm{Cl}_{2}(10 \mathrm{~mL})$ at $-10{ }^{\circ} \mathrm{C}$. The solution was allowed to warm to room temperature and stir for $24 \mathrm{~h}$. The solution was diluted with $\mathrm{H}_{2} \mathrm{O}(150 \mathrm{~mL})$ and extracted 
with $\mathrm{CH}_{2} \mathrm{Cl}_{2}(3 \times 100 \mathrm{~mL})$. The extracts were combined, dried, and concentrated under reduced pressure to provide an oil. The resulting oil was purified on silica gel chromatography using petroleum ether and acetone (9.5:0.5) as eluents to provide an inseparable mixture of product and starting alkene. This mixture was then dissolved in $\mathrm{CH}_{2} \mathrm{Cl}_{2}(150 \mathrm{~mL})$ and cooled to $-78{ }^{\circ} \mathrm{C}$. Ozone $(\mathrm{g})$ was bubbled through the solution until a blue green color persisted and dimethyl sulfide was added to quench the reaction. The reaction was allowed to warm to room temperature and was concentrated under reduced pressure. The resulting oil was purified on silica gel using petroleum ether and acetone (9.5:0.5) as eluents to afford 26 as a colorless oil $(5.44 \mathrm{~g}, 41 \%) .{ }^{1} \mathrm{H} \mathrm{NMR}(300 \mathrm{MHz}$, $\mathrm{CDCl}_{3}$ ) $\delta 7.19$ (br. s, $1 \mathrm{H}$ ), 6.79 (br. d, 2H), 6.51 (br. s, $1 \mathrm{H}$ ), 4.49 (br. s, $1 \mathrm{H}$ ), 4.15 (br. s, $1 \mathrm{H}$ ), 3.41 (br. d, $J=7.8 \mathrm{~Hz}, 2 \mathrm{H}$ ), 2.92 (br. s, $1 \mathrm{H}$ ), 2.33 (sept., $J=4.8 \mathrm{~Hz}, 1 \mathrm{H}$ ), 2.17 (t, $J=7.1 \mathrm{~Hz}$, $1 \mathrm{H}), 1.28(\mathrm{~d}, J=5.7 \mathrm{~Hz}, 6 \mathrm{H}), 0.73(\mathrm{~d}, J=6.9 \mathrm{~Hz}, 3 \mathrm{H})$.

(1R,5R,6S)-5-Methyl-6-[3-(1-methylethoxy)phenyl]-3-azabicyclo[4.1.0]heptane (27a)-Sodium wire was added in small pieces to 26 (5.44 g, $0.010 \mathrm{~mol})$ in a solution of tert-butanol $(135 \mathrm{~mL})$, THF $(135 \mathrm{~mL})$, and liquid $\mathrm{NH}_{3}(270 \mathrm{~mL})$ at $-78{ }^{\circ} \mathrm{C}$ until a blue color persisted for $10 \mathrm{~min}$. Solid $\mathrm{NH}_{4} \mathrm{Cl}(10 \mathrm{~g})$ was added, and the resulting suspension was allowed to warm to room temperature over $8 \mathrm{~h}$. Water $(100 \mathrm{~mL})$ was added, and the biphasic mixture was extracted with $\mathrm{CH}_{2} \mathrm{Cl}_{2}(3 \times 75 \mathrm{~mL})$. The extracts were combined, dried $\left(\mathrm{MgSO}_{4}\right)$, and concentrated under reduced pressure to afford an oil. The oil was purified using silica gel chromatography $\left(\mathrm{CHCl}_{3}, \mathrm{MeOH}, \mathrm{NH}_{4} \mathrm{OH} ; 95: 4.5: 0.5\right)$ to provide $27 \mathbf{a}$ (1.58 g, $64 \%)$ as a pale yellow oil. ${ }^{1} \mathrm{H}$ NMR $\left(300 \mathrm{MHz}, \mathrm{CDCl}_{3}\right) \delta 7.11(\mathrm{t}, J=9.0 \mathrm{~Hz}, 1 \mathrm{H}), 6.81(\mathrm{~d}$, $J=9.0 \mathrm{~Hz}, 1 \mathrm{H}), 6.79(\mathrm{~s}, 1 \mathrm{H}), 6.68(\mathrm{~d}, J=9.0 \mathrm{~Hz}, 1 \mathrm{H}), 4.51$ (sept., $J=6.0 \mathrm{~Hz}, 1 \mathrm{H}), 4.24(\mathrm{dd}$, $J=12.0,6.0 \mathrm{~Hz}, 1 \mathrm{H}), 3.11(\mathrm{~d}, J=12.0 \mathrm{~Hz}, 1 \mathrm{H}), 2.78(\mathrm{dd}, J=12.0,6.0 \mathrm{~Hz}, 1 \mathrm{H}), 2.24(\mathrm{dd}, J$ $=12.0,9.0 \mathrm{~Hz}, 1 \mathrm{H}), 2.03(\mathrm{q}, J=6.0 \mathrm{~Hz}, 1 \mathrm{H}), 1.31-1.29(\mathrm{~m}, 2 \mathrm{H}), 1.30(\mathrm{~d}, J=6.0 \mathrm{~Hz}, 6 \mathrm{H})$, $0.89-0.79(\mathrm{~m}, 2 \mathrm{H}), 0.65(\mathrm{~d}, J=9.0 \mathrm{~Hz}, 3 \mathrm{H}) ;{ }^{13} \mathrm{C}-\mathrm{DEPT} 135 \mathrm{NMR}\left(75 \mathrm{MHz}, \mathrm{CDCl}_{3}\right) \delta 129.1$ $(\mathrm{CH}), 122.9(\mathrm{CH}), 118.6(\mathrm{CH}), 113.5(\mathrm{CH}), 70.1(\mathrm{CH}), 51.2\left(\mathrm{CH}_{2}\right), 45.1\left(\mathrm{CH}_{2}\right), 33.6(\mathrm{CH})$, $22.5\left(\mathrm{CH}_{3}\right), 19.0(\mathrm{CH}), 18.8\left(\mathrm{CH}_{2}\right), 18.3\left(\mathrm{CH}_{3}\right)$.

\section{3-[(1R,5R,6S)-5-Methyl-3-azabicyclo[4.1.0]hept-6-yl]phenol (27b)—A $1.0 \mathrm{M}$} solution of $\mathrm{BCl}_{3}$ in $\mathrm{CH}_{2} \mathrm{Cl}_{2}(38.64 \mathrm{~mL}, 38.64 \mathrm{mmol})$ was added dropwise to a solution of 27a (1.58 g, $0.064 \mathrm{~mol})$ in $\mathrm{CH}_{2} \mathrm{Cl}_{2}(45 \mathrm{~mL})$ at $-78{ }^{\circ} \mathrm{C}$ under $\mathrm{N}_{2}$. The solution was allowed to stir for $2 \mathrm{~h}$ and then allowed to warm to room temperature. The reaction was quenched with saturated $\mathrm{NaHCO}_{3}(25 \mathrm{~mL})$ and extracted with $\mathrm{CH}_{2} \mathrm{Cl}_{2}(3 \times 50 \mathrm{~mL})$. The resulting extracts were combined, dried $\left(\mathrm{MgSO}_{4}\right)$, and concentrated under reduced pressure to afford an oil. The oil was purified using Brockman III neutral alumina chromatography with $\mathrm{CH}_{2} \mathrm{Cl}_{2}$ and $\mathrm{MeOH}(9.5: 0.5)$ as eluents to afford $27 \mathrm{~b}(0.20 \mathrm{~g}, 15 \%)$ as an oil. ${ }^{1} \mathrm{H} \mathrm{NMR}(300 \mathrm{MHz}$, $\left.\mathrm{CDCl}_{3}\right) \delta 7.10(\mathrm{t}, J=9.0 \mathrm{~Hz}, 1 \mathrm{H}), 6.78(\mathrm{~d}, J=7.5 \mathrm{~Hz}, 1 \mathrm{H}), 6.72(\mathrm{t}, J=1.8 \mathrm{~Hz}, 1 \mathrm{H}), 6.63$ (ddd, $J=7.8,2.4,0.6 \mathrm{~Hz}, 1 \mathrm{H}), 4.35$ (br. s, $2 \mathrm{H}), 3.40$ (dd, $J=13.3,5.4 \mathrm{~Hz}, 1 \mathrm{H}), 3.16$ (d, $J=$ $13.2 \mathrm{~Hz}, 1 \mathrm{H}), 2.84(\mathrm{dd}, J=13.1,4.7 \mathrm{~Hz}, 1 \mathrm{H}), 2.36(\mathrm{dd}, J=12.9,8.1 \mathrm{~Hz}, 1 \mathrm{H}), 2.09-1.98(\mathrm{~m}$, $1 \mathrm{H}), 1.37-1.32(\mathrm{~m}, 1 \mathrm{H}), 0.96(\mathrm{dd}, J=9.0,4.5 \mathrm{~Hz}, 1 \mathrm{H}), 0.79(\mathrm{t}, J=5.3 \mathrm{~Hz}, 1 \mathrm{H}), 0.70(\mathrm{~d}, J=$ $6.9 \mathrm{~Hz}, 3 \mathrm{H})$. 


\section{X-ray Crystal Structure of 6 and 27a}

Single-crystal X-ray diffraction data on compounds 6 and 27a were collected using Mo Ka radiation and an APEX $2 \mathrm{CCD}$ area detector and $\mathrm{Cu} \mathrm{Ka}$ radiation and a Bruker Platimun-135 CCD area detector, respectively. The structures was solved by direct methods and refined by full-matrix least-squares on $F^{2}$ values using the programs found in the SHELXTL suite (SHELXTL v6.10, 2000). Parameters refined included atomic coordinates and anisotropic thermal parameters for all non-hydrogen atoms. Hydrogen atoms on carbons were included using a riding model [coordinate shifts of $\mathrm{C}$ applied to $\mathrm{H}$ atoms] with the $\mathrm{C}-\mathrm{H}$ distance set at $0.96 \AA$. Atomic coordinates for these compounds have been deposited with the Cambridge Crystallographic Data Centre (deposition numbers 1480747 and 1480746 for compounds 6 and 27a, respectively). Copies of the data can be obtained, free of charge, on application to CCDC, 12 Union Road, Cambridge, CB2 1EZ, U.K. [fax: + 44(0)-1223-336033 or e-mail: deposit@ccdc.cam.ac.uk].

$6(X 1)$

A $0.205 \times 0.143 \times 0.025 \mathrm{~mm}^{3}$ crystal of $\mathbf{X} \mathbf{1}$ was prepared for data collection coating with high viscosity microscope oil. The oil-coated crystal was mounted on a glass rod and transferred immediately to the cold stream $(218 \mathrm{~K})$ on the diffractometer. The crystal was monoclinic in space group $P 2_{1}$ with unit cell dimensions $a=7.5585$ (2) $\AA, b=7.1426(2) \AA, c$ $=19.8369(5) \AA$, and $\beta=97.549(2)^{\circ}$. Corrections were applied for Lorentz, polarization, and absorption effects. Data were $99.6 \%$ complete to $29.01^{\circ} \theta$ (approximately $0.73 \AA$ ) with an average redundancy of 4.0. The reference molecule $((R, R)$-tartaric acid) was disordered over two positions with an occupancy ratio of 8:2. The lower occupancy position was modeled using constraints in SHELX to fix the bond lengths and angles while allowing the atom positions and torsion angles to refine.

27a (X2)

A $0.196 \times 0.063 \times 0.024 \mathrm{~mm}^{3}$ crystal of $\mathbf{X} \mathbf{2}$ was prepared for data collection coating with high viscosity microscope oil. The oil-coated crystal was mounted on a glass rod and transferred immediately to the diffractometer and data collected at room temperature (296 $\mathrm{K})$. The crystal was monoclinic in space group $P 2_{1} / c$ with unit cell dimensions $a=7.9239$ (3) $\AA, b=16.0550(7) \AA, c=8.1077(4) \AA$, and $\beta=100.693(2)^{\circ}$. Corrections were applied for Lorentz, polarization, and absorption effects. Data were $89.2 \%$ complete to $67.71^{\circ} \theta$ (approximately $0.83 \AA$ ) with an average redundancy of 4.7 .

\section{$\left[{ }^{35}\right.$ S]GTP $\gamma$ S Assays}

The $\left[{ }^{35} \mathrm{~S}\right] \mathrm{GTP} \gamma \mathrm{S}$ assays were conducted using the methods previously reported. ${ }^{16}$

\section{Supplementary Material}

Refer to Web version on PubMed Central for supplementary material. 


\section{Acknowledgments}

This research was supported by the National Institute on Drug Abuse Grant DA12001. X-ray crystallographic work was supported by NIDA through Interagency Agreement Number ADA 12003-005 with the Naval Research Laboratory (NRL).

\section{References}

1. Carroll FI, Dolle RE. Chem Med Chem. 2014; 9:1638. [PubMed: 24981721]

2. Buda JJ, Carroll FI, Kosten TR, Swearingen D, Walters BB. Neuropsychopharmacology. 2015; 40:2059. [PubMed: 25628006]

3. Wu H, Wacker D, Mileni M, Katritch V, Han GW, Vardy E, Liu W, Thompson AA, Huang XP, Carroll FI, Mascarella SW, Westkaemper RB, Mosier PD, Roth BL, Cherezov V, Stevens RC. Nature. 2012; 485:327. [PubMed: 22437504]

4. Kormos CM, Cueva JP, Gichinga MG, Runyon SP, Thomas JB, Brieaddy LE, Mascarella SW, Gilmour BP, Navarro HA, Carroll FI. J Med Chem. 2014; 57:3140. [PubMed: 24635568]

5. Mchardy, SF., Liras, S., Heck, SD. WO. 2003035622A1. 2003.

6. Brooks PR, Wirtz MC, Vetelino MG, Rescek DM, Woodworth GF, Morgan BP, Coe JW. J Org Chem. 1999; 64:9719.

7. Lebel H, Marcoux J-F, Molinaro C, Charette AB. Chem Rev. 2003; 103:977. [PubMed: 12683775]

8. Micheli F, Cavanni P, Arban R, Benedetti R, Bertani B, Bettati M, Bettelini L, Bonanomi G, Braggio S, Checchia A, Davalli S, Di Fabio R, Fazzolari E, Fontana S, Marchioro C, Minick D, Negri M, Oliosi B, Read KD, Sartori I, Tedesco G, Tarsi L, Terreni S, Visentini F, Zocchi A, Zonzini L. J Med Chem. 2010; 53:2534. [PubMed: 20170186]

9. Molchanov SA, Stepakov AV, Kostikov RR. Russian Journal of Organic Chemistry. 2000; 36:933.

10. Olofson RA, Martz JT, Senet JP, Piteau M, Malfroot T. J Org Chem. 1984; 49:2081.

11. Robinson GC. Tetrahedron Lett. 1965; 6:1749.

12. Kelly DP, Banwell MG, Ireland NK, Noel AL. J Org Chem. 1991; 56:2040.

13. Casy AF, Dewar GH, Al-Deeb OAA. Chirality. 1989; 1:202. [PubMed: 2561991]

14. Casy AF, Dewar GH, Al-Deeb OAA. Magn Reson Chem. 1989; 27:964.

15. Werner JA, Cerbone LR, Frank SA, Ward JA, Labib P, Tharp-Taylor RW, Ryan CW. J Org Chem. 1996; 61:587. [PubMed: 11666979]

16. Carroll FI, Chaudhari S, Thomas JB, Mascarella SW, Gigstad KM, Deschamps J, Navarro HA. J Med Chem. 2005; 48:8182. [PubMed: 16366600]

J Org Chem. Author manuscript; available in PMC 2017 September 06. 


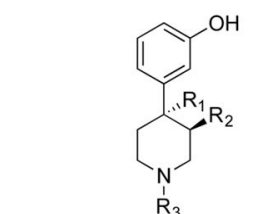

$1 \mathrm{R}_{1}=\mathrm{R}_{2}=\mathrm{CH}_{3}$

$2 \mathrm{R}_{1}=\mathrm{R}_{2}=\mathrm{H}, \mathrm{R}_{3}=\mathrm{CH}_{3}$

$3 \mathrm{R}_{1}=\mathrm{R}_{3}=\mathrm{CH}_{3}, \mathrm{R}_{2}=\mathrm{H}$

$4 \mathrm{R}_{1}=\mathrm{R}_{2}=\mathrm{R}_{3}=\mathrm{CH}_{3}$

$5 \mathrm{R}_{1}=\mathrm{R}_{2}=\mathrm{CH}_{3}, \mathrm{R}_{3}=2$-methylcinnamyl LY255582
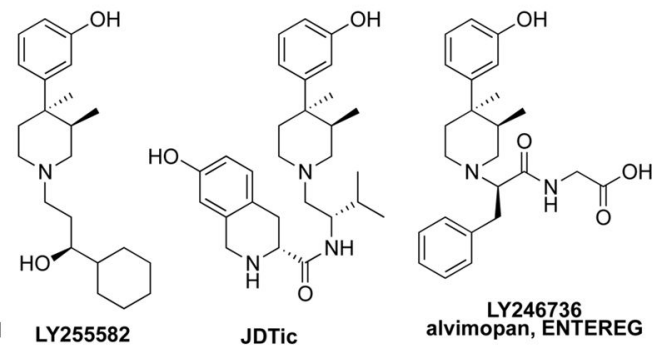

JDTic

LY246736
alvimopan, ENTEREG
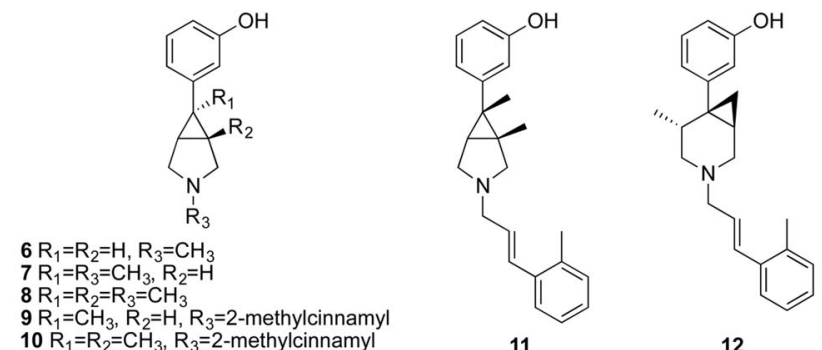

12

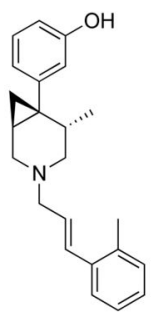

13

Figure 1.

Structures of 1-5, LY255582, JDTic, alvimopan, and 6-13. 
<smiles>[R1]NCCC(C)(c1cccc(O)c1)C(C)C</smiles>

1<smiles>[R1]N1C[C@H]2C[C@@]([R2])(C2)C1(C)c1cccc(O)c1</smiles>

7, $9 \mathrm{R}_{2}=\mathrm{H}$

$8,10 \mathrm{R}_{2}=\mathrm{CH}_{3}$<smiles>[R1]N[C@@H]1C[C@@]2(C)C[C@H]1C2(C)c1cccc(O)c1</smiles>

11

Figure 2.

Conformational representation of general structure 1 and the (1a,5a,6a)-compounds 7-10 as compared to the $(1 a, 5 a, 6 \beta)-11$. 


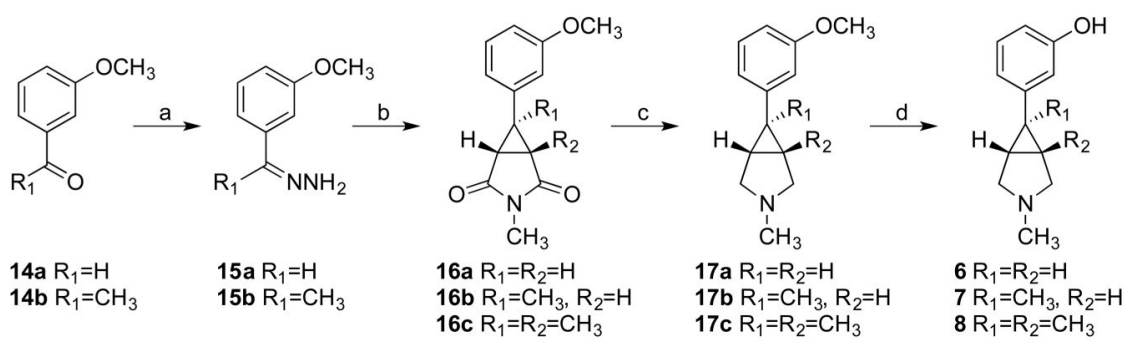

Scheme 1. Synthesis of Compounds 6-8 ${ }^{a}$

aReagents: (a) $\mathrm{NH}_{2} \mathrm{NH}_{2} \cdot \mathrm{H}_{2} \mathrm{O}$; (b) (1) $\mathrm{MnO}_{2}$, dioxane, (2) 1-methylmaleimide or 1,3dimethylmaleimide, THF, reflux; (c) $\mathrm{NaBH}_{4}, \mathrm{BF}_{3} \cdot(\mathrm{OEt})_{2}$, THF; (d) $\mathrm{BBr}_{3}, \mathrm{CH}_{2} \mathrm{Cl}_{2}$. 


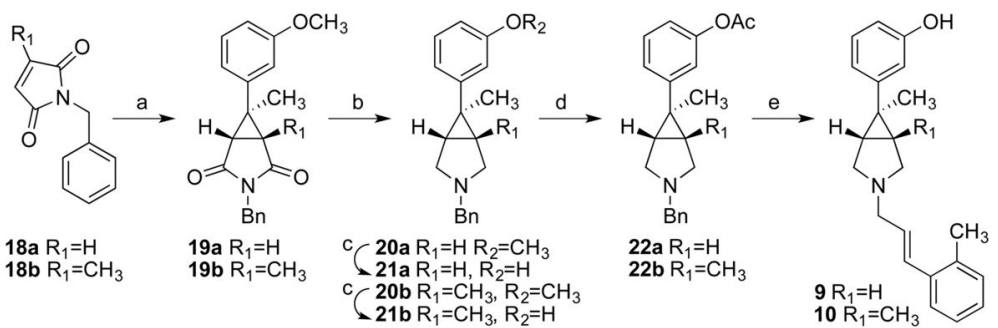

Scheme 2. Synthesis of Compounds 9 and $10^{\mathrm{a}}$

aReagents: (a) 1-(3-Methoxyphenyl)-diazoethane, dioxane, reflux; (b) $\mathrm{NaBH}_{4}, \mathrm{BF}_{3} \cdot(\mathrm{OEt})_{2}$, THF; (c) $\mathrm{BCl}_{3}$, TBAI, $\mathrm{CH}_{2} \mathrm{Cl}_{2}$; (d) (1) $\mathrm{NaOH},\left(\mathrm{NBu}_{4}\right)_{2} \mathrm{SO}_{4}$, dioxane or $\mathrm{NaH}$, THF, (2)

$\mathrm{AcCl}$; (e) (1) $\mathrm{Pd} / \mathrm{C}, \mathrm{H}_{2}, \mathrm{HCl}, \mathrm{EtOH}$, (2) trans-2-methylcinnamaldehyde, $\mathrm{NaBH}(\mathrm{OAc})_{3}, 1,2-$ dichloroethane; (3) $\mathrm{K}_{2} \mathrm{CO}_{3}, \mathrm{CH}_{3} \mathrm{OH}$ (aq). 


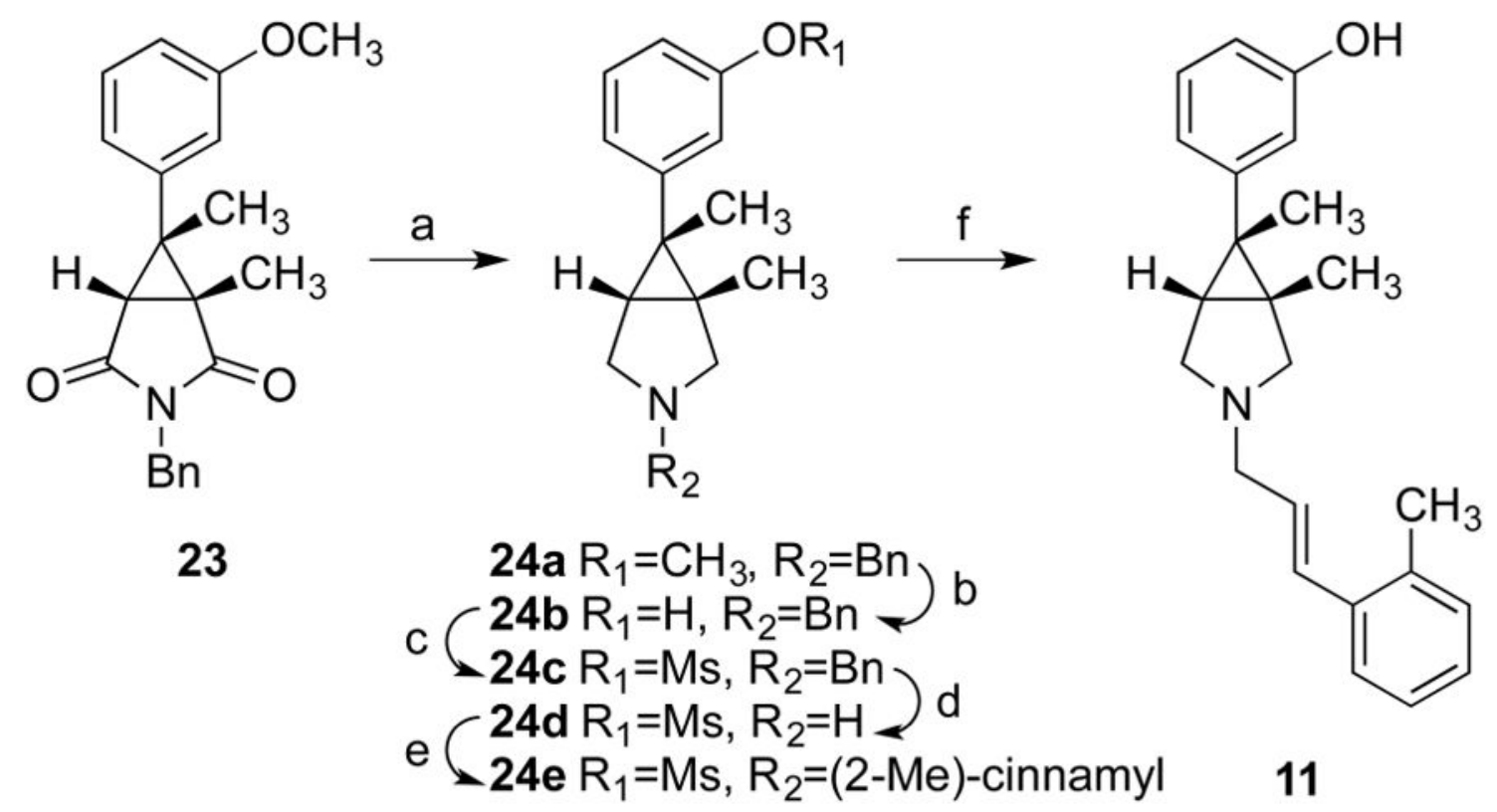

Scheme 3. Synthesis of Compound $11^{\mathrm{a}}$

a Reagents: (a) $\mathrm{NaBH}_{4}, \mathrm{BF}_{3} \cdot(\mathrm{OEt})_{2}$, THF; (b) $\mathrm{BCl}_{3}$, TBAI, $\mathrm{CH}_{2} \mathrm{Cl}_{2}$; (c) $\mathrm{MsCl}$, pyridine; (d)

$\mathrm{Pd} / \mathrm{C}, \mathrm{EtOH}, \mathrm{HCl}, \mathrm{H}_{2}$; (e) trans-2-methylcinnamaldehyde, $\mathrm{NaBH}(\mathrm{OAc})_{3}, 1,2$ -

dichloroethane; (f) $\mathrm{NaOH}, \mathrm{CH}_{3} \mathrm{OH}$. 


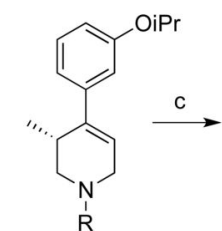

a $25 \mathrm{a} \mathrm{R}=\mathrm{CH}_{3}$ $\begin{aligned} 25 b \mathrm{R} & =\mathrm{H} \\ 25 \mathrm{c} & =\mathrm{Tf}\end{aligned}$
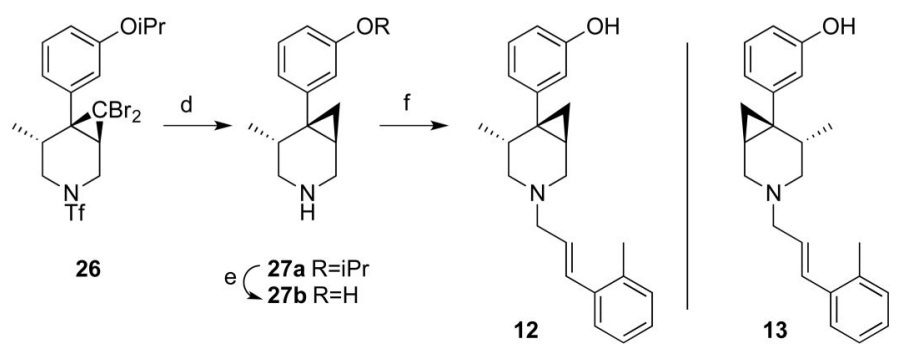

Scheme 4. Synthesis of Compounds 12 and $13^{\mathrm{a}}$

a Reagents: (a) (1) 1-Chloroethyl chloroformate, 1,2-dichloroethane, (2) $\mathrm{CH}_{3} \mathrm{OH}$; (b) $\mathrm{Tf}_{2} \mathrm{O}$, $\mathrm{NEt}_{3}, \mathrm{CH}_{2} \mathrm{Cl}_{2}$; (c) (1) $\mathrm{NaOH}, \mathrm{CHBr}_{3}, \mathrm{BnNMe}_{3} \mathrm{Cl}, \mathrm{EtOH}, \mathrm{CH}_{2} \mathrm{Cl}_{2}$, (2) $\mathrm{O}_{3}, \mathrm{CH}_{2} \mathrm{Cl}_{2}$, (3)

$\mathrm{S}\left(\mathrm{CH}_{3}\right)_{2}$; (d) $\mathrm{Na}, \mathrm{tBuOH}, \mathrm{THF}, \mathrm{NH}_{3}$; (e) $\mathrm{BCl}_{3}, \mathrm{CH}_{2} \mathrm{Cl}_{2}$; (f) trans-2-methylcinnamaldehyde, $\mathrm{NaBH}(\mathrm{OAc})_{3}, 1,2$-dichloroethane. 
Table 1

Inhibition of Agonist-Stimulated [35S]GTP $\gamma \mathrm{S}$ Binding in Cloned Human $\mu, \delta, \kappa$ Opioid Receptors

\begin{tabular}{llll}
\hline compound & $\begin{array}{l}\boldsymbol{\mu}, \text { DAMGO } \\
\boldsymbol{K}_{\mathbf{e}}(\mathbf{n M})\end{array}$ & $\begin{array}{l}\boldsymbol{\delta}, \mathbf{D P D P E} \\
\boldsymbol{K}_{\mathbf{e}}(\mathbf{n M})\end{array}$ & $\begin{array}{l}\boldsymbol{\kappa}, \mathbf{U 6 9 , 5 9 3} \\
\boldsymbol{K}_{\mathbf{e}}(\mathbf{n M})\end{array}$ \\
\hline $\mathbf{7}$ & $241 \pm 65$ & $2390 \pm 440$ & $479 \pm 130$ \\
$\mathbf{6}$ & $\mathrm{IA}^{a}$ & $\mathrm{IA}^{a}$ & $>8000$ \\
$\mathbf{8}$ & $18 \pm 6$ & $244 \pm 75$ & $42 \pm 10$ \\
$\mathbf{9}$ & $0.48 \pm 0.02$ & $8.8 \pm 3$ & $2.9 \pm 1$ \\
$\mathbf{1 0}$ & $0.02 \pm 0.01$ & $0.74 \pm 0.3$ & $0.39 \pm 0.2$ \\
$\mathbf{1 1}$ & $54.6 \pm 17$ & $85 \pm 26$ & $\mathrm{IA}^{a}$ \\
$\mathbf{1 3}$ & $3.5 \pm 1$ & $156 \pm 90$ & $50.2 \pm 14$ \\
$\mathbf{1 2}$ & $0.42 \pm 0.02$ & $89 \pm 46$ & $40.8 \pm 15$ \\
$\mathbf{2}^{b}$ & $\mathrm{IA}^{a}$ & $\mathrm{IA}^{a}$ & $2700 \pm 1300$ \\
$\mathbf{3}^{b}$ & $974 \pm 230$ & $\mathcal{c}$ & $479 \pm 150$ \\
$\mathbf{4}^{b}$ & $29.3 \pm 3$ & $681 \pm 240$ & $134 \pm 27$ \\
$\mathbf{5}$ & $0.08 \pm 0.03$ & $1.21 \pm 0.4$ & $0.44 \pm 0.2$ \\
$a_{\text {IA }}{ }^{b}$ inactive. & & & \\
$b_{\text {Data taken from ref } 4 .}$ & & \\
$\boldsymbol{c}_{\mathbf{3}}$ was an agonist, ED $50=8300 \pm 2500$ with & $E_{\mathrm{max}}=6490 \pm 590$ of DPDPE max.
\end{tabular}

